
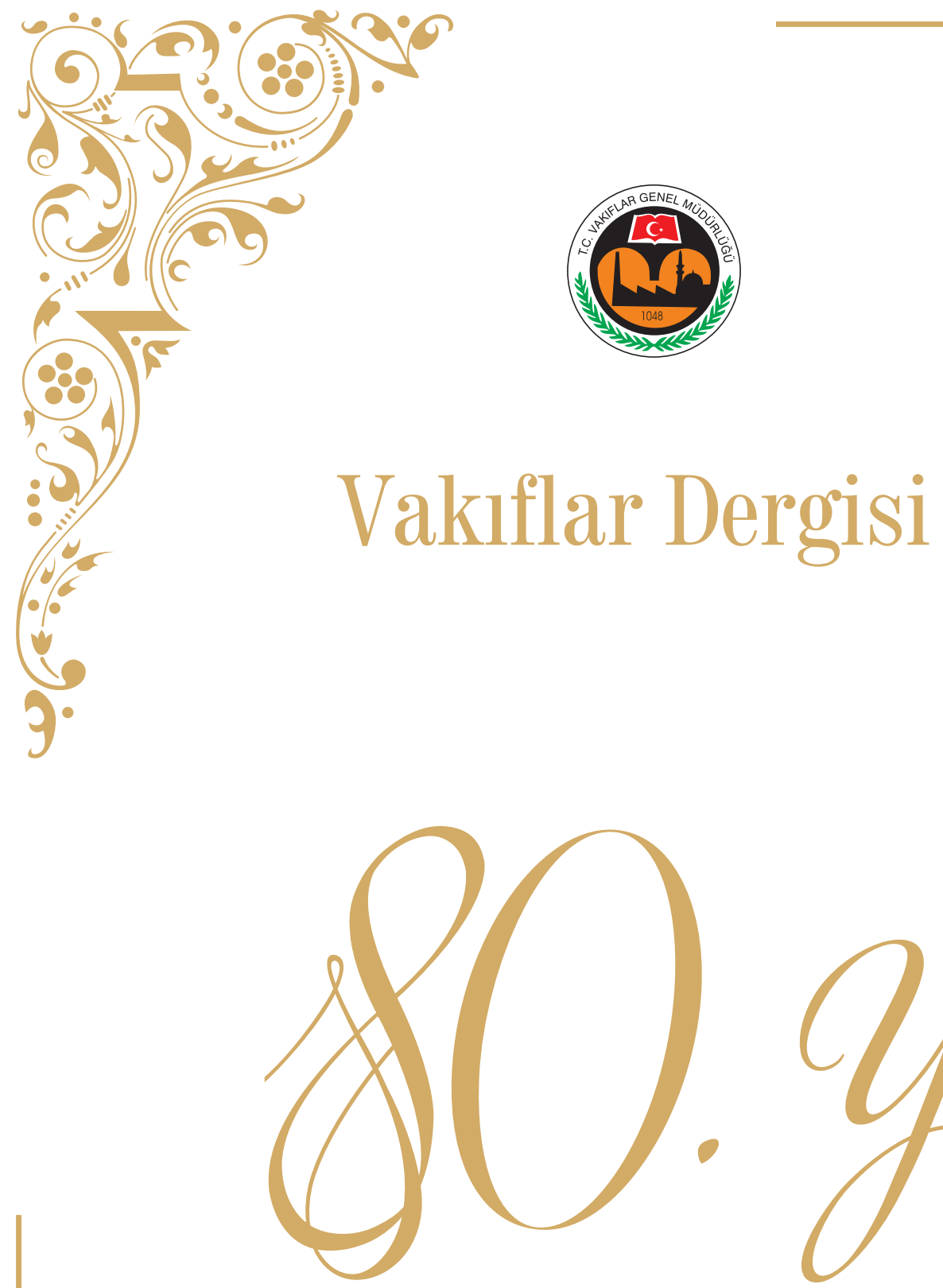

Ankara 2019

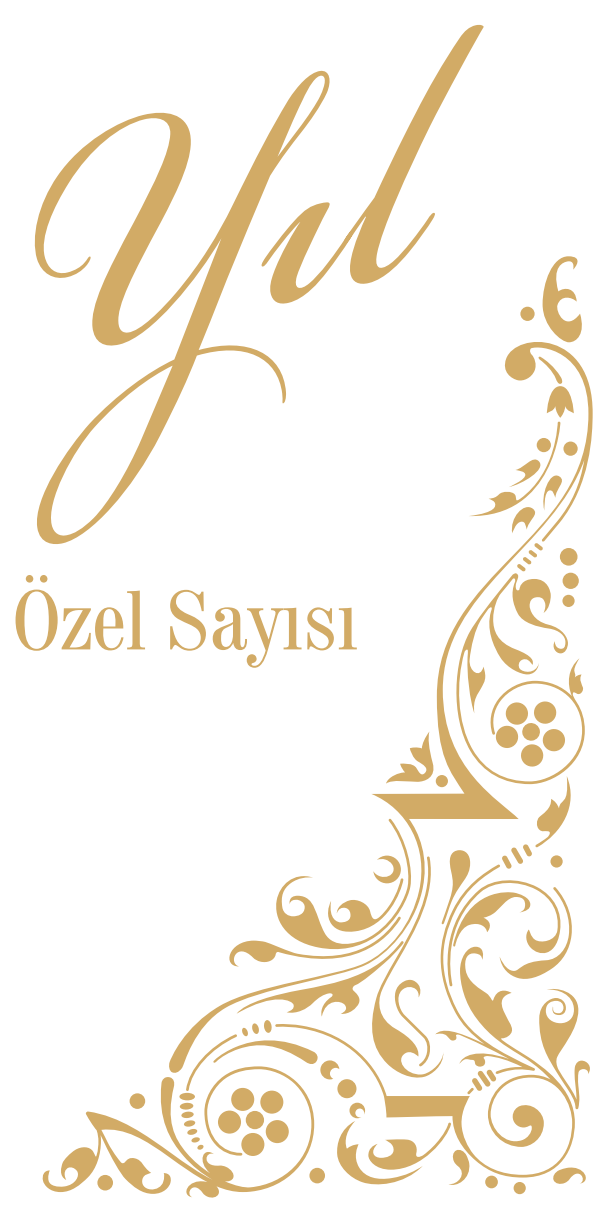




\section{VAKIFLAR DERGISI}

Yıl: 2019 - 80.Yıl Özel Sayısı - Hakemli Dergidir.

TÜBITAK ULAKBIM

Sosyal Bilimler Veri Tabanı (SBVTं) tarafindan taranmaktadır.

$$
\begin{gathered}
\text { Sertifika No: } 16651 \\
\text { ISSN: } 1011-7474 \\
\text { e-ISSN: } 2564-6796 \\
\text { Sahibi }
\end{gathered}
$$

Vakıflar Genel Müdürlüğü Adına

Dr. Adnan ERTEM

Yayın Koordinatörü

Rifat TÜRKER

Sorumlu Yazı Işleri Müdürü

Mevlüt ÇAM

Yayın Yönetmeni

Mehmet KURTOĞLU

Editörler

Hüseyin ÇINAR, Fatih MÜDERRISOĞLU

İngilizce Editörü

Miyase KOYUNCU KAYA

Tashih

Hasan DEMIRTAS

Dergi Sekreteryası

Hasan DEMIRTAŞ

Yayın Kurulu

Prof.Dr. Mehmet BULUT İstanbul Sabahattin Zaim Üniversitesi

Prof. Dr. Hüseyin CINAR Ankara Yıldırım Beyazıt Üniversitesi

Prof.Dr. Yılmaz KURT Ankara Üniversitesi (Emekli)

Prof.Dr. Mehmet ÖZ Hacettepe Üniversitesi

Prof.Dr. Ali YILMAZ Uşak Üniversitesi

Doç.Dr. Miyase KOYUNCU KAYA Ankara Yıldııım Beyazıt Üniversitesi

Dr. Öğr. Üyesi Fatih MÜDERRiSOĞLU Hacettepe Üniversitesi

Dr. Murat YILMAZ Ahmet Yesevi Üniversitesi

Yayın Danışma Kurulu

Prof. Dr. Mahmut AK İstanbul Üniversitesi

Prof. Dr. Enver ÇAKAR FIrat Üniversitesi

Prof.Dr. Abide DOĞAN Hacettepe Üniversitesi

Prof. Dr. Géza DAVID Macar Bilimler Akademisi

Prof. Dr. Abdullah EKiNCi Harran Üniversitesi

Prof. Dr. Özer ERGENÇ Bilkent Üniversitesi

Prof. Dr. Süreyya FAROQHI Bilgi Üniversitesi

Prof.Dr. Zekeriya KURŞUN Fatih Sultan Mehmet Vakıf Üniversitesi

Prof. Dr. Mahmut KAYA Ankara Üniversitesi (Emekli)

Prof.Dr. Yunus KOC Hacettepe Üniversitesi

Prof. Dr. Heath W. LOWRY Bahçeșehir Üniversitesi

Prof.Dr. ilber ORTAYLI MEF Üniversitesi

Prof. Dr. Hüsrev SUBAŞI Fatih Sultan Mehmet Vakıf Üniversitesi

Prof.Dr. Eugenia KERMELI ÜNAL Hacettepe Üniversitesi

Prof.Dr. Ayşııl TUUKEL YAVUZ Orta Doğu Teknik Üniversitesi (Emekli)

Prof.Dr. Bahaeddin YEDIYILDIZ Hacattepe Üniversitesi (Emekli)

Prof. Dr. Musa YILDIZ Ahmet Yesevi Üniversitesi

Dr. Öğr. Üyesi Vefa ÇOBANOĞLU İstanbul Üniversitesi

Dr. Rhoads MURPHEY Birmingham Üniversitesi (Emekli)

Evangeila BALTA Ulusal Yunan Araştırma Vakfi / Yunanistan

Mehmet Çetin Araştrmacı

Yayın ve Danışma Kurullarındaki isimler unvan ve soyadına göre alfabetik olarak sıralanmıştır.

Dergimize gönderilen yazılar, önce yayın kurulunca incelenir ve uygun bulunanlar, değerlendirilmek üzere alanında çalışması ile tanınmış iki hakeme gönderilir. Hakemlerin isimleri gizli tutulur ve raporlar beş yıl süreyle saklanır. Dergide çıkan yazılar kaynak gösterilerek iktibas edilebilir. Yayınlanan yazı, belge ve fotoğrafların her türlü hukuki mesuliyeti yazarına aittir.

\section{Yazışma Adresi:}

T.C.

Vakıflar Genel Müdürlüğü Kültür ve Tescil Daire Bașkanlığı

Vakıflar Dergisi Atatürk Bulvarı. No: 1006050 Ulus / ANKARA / TÜRKiYE

Tel: (0312) 5096000 - Faks: (0312) 3244722

e-posta: vakiflaryayin@yahoo.com - web: www.vgm.gov.tr 


\title{
IÇiNDEKILER / CONTENT
}

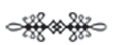

Vakıflar Hangi Statüde Bir İdarî Yapı İle Yönetilmelidir?

What should be the Statute and Administrative Structure of Waqfs?

Nazif Öztürk

İktisat Tarihi Açısından Vakıflar 73

Waqfs From The Perspective Of History Of Economics

Murat Çizakça

Nakid Para Vakfi İle İlgili Çivi-zâde'nin Ebussu'ûd’a Yazdığı Reddiye Risâlesi

Refutation of Chiwi-zadah against Abussu'ud Effendi on Cash Waqfs

Ahmet Akgündüz

Gelenekçi Osmanlı Islahat Düşüncesinde Temlikler ve Vakıflar

Waqfs and Temliks (Freehold Properties) in Traditional Ottoman Reform Thought

Mehmet Öz

Osmanlı Finansal Zihniyetinin Bir Göstergesi Olarak Para Vakıflarına Bir Bakış

A Look at the Cash Waqfs as an Indicator of Ottoman Financial Mentality

Mehmet Bulut - Cem Korkut

Osmanlı Su Yapılarında Vakıfların Rolü: Tesis, Onarım ve Hizmet Giderlerinin Finansmanı

Role of Waqfs in Ottoman Water Structures: Financing the Construction, Repair and Service Expenses

Said Öztürk

Muhasebe Kayıtları Işığında Mektep Vakıflarının Gelir Giderleri: 18. Yüzyıl Sonları Üsküdar Örneği ......

Income and Expenses of the School Waqfs in the Light of Accounting Records: Example of the Late 18th Century Üsküdar

Süleyman Kaya - Muhammed Emin Durmuş

Tuna Sahilinde On Altıncı Yüzyılda Kurulmuş Bir Osmanlı Yerleşimi: İsmail Geçidi Kasabası ..... 189

An Ottoman Town situated in the basin of Danube at the end of the sixteenth century: The town of İsmail Geçidi Mehmet Akif Erdoğru

Dedebalıların İzinde II: Dedebalı Zaviyesi ve Harmancık Kazası Dedebalı Karyesi

In Pursuit of Dedebali Community II: Dedebali Zawiyah and Dedebali Village of Harmancik District

Saim Savaş

Vakıf Medeniyeti.

Prof. Dr. Halil İnalcık

Prof. Dr. İlber Ortaylı İle Vakıf Medeniyeti Üzerine

Mahmut Bıyıkı

Semavi Eyice İle Bir Sohbet Bir Konferans

M. Sacit Pekak 
Bir Çınarın Ardından: Prof Dr. Hakkı Acun'un Yaşam Öyküsü ve Bilimsel Kişiliği.

M.Fatih Müderrisoğlu - Bülent İşler

Orhan Cezmi Tuncer: Her Vakıf Yapısında Tanrısal Güzelliği Gördüm .....

Mehmet Kurtoğlu

Hocası Prof. Dr. Rahmi Hüseyin Ünal'ın Kaleminden Sanat Tarihçi Yekta Demiralp

307

Rahmi Hüseyin Ünal

Türkiye'deki Bizans Sanatı Tarihinin Bir Çınarı: Hocam Prof. Dr. Yıldız Ötüken

311

Zeynep Mercangöz

Geçmişten Geleceğe Bir Vizyon Çizmek (Vakıflar Genel Müdürlüğü Yayıncılığı).

Publishing of General Directorate of Foundations; A Visionary Look From Past to Future

Mehmet Kurtoğlu

Vakıflar Dergisi 2013-2019 Yayın Dönemi (40-50. Sayılar) Değerlendirmesi ve Bibliyografyası

Waqfs Journal 2013-2019 Publication Period (40-50 issues) Evaluation and Bibliography

Hasan Demirtaş 


\title{
Muhasebe Kayıtları Işı̆̆ında Mektep Vakıflarının Gelir Giderleri: 18. Yüzyll Sonları Üskïdar Örneği* Süleyman Kaya**
Muhammed Emin Durmuş***
}

$\ddot{O ̈ z}$

Osmanlı vakıflarının faaliyet gösterdikleri en önemli alanlardan biri eğitimdir. Osmanlı'da eğitim hizmetleri 19. yüzyılda Maarif Nezareti kuruluncaya dek vakıflar tarafından yürütülmüştür. Vakıfların halka yönelik eğitim verdikleri kurumların başında da sıbyan mektepleri gelmektedir. Bu çalışmada mektep vakıflarının hizmetlerini nasıl finanse ettikleri, ne tür yerlere ne kadar masraf yaptıkları, bünyelerinde hangi görevlileri istihdam ettirdikleri ve bu görevlilere ne kadar maaş ödedikleri sorularına Üsküdar örneği üzerinden cevap verilmeye çalışılmıştır.

Çalışmada 1184-1214/1770-1800 tarihlerinde Üsküdar'da faaliyet gösterdiğini tespit ettiğimiz 5 adet mektep vakfının süreç içerisindeki gelir ve giderlerinin analiz edilmesi hedeflenmiştir. Çalışma neticesinde nakit sermaye işleten vakıfların zaman içerisinde sermayelerini artırdıkları bunun yanı sıra vakıfların vazifelilere ödedikleri toplam maaş miktarının genel olarak masraf kalemlerine yapılan harcamalardan yüksek olduğu ve vazifelilere ödenen yıllık ücretlerin bu süre zarfinda istisnalar hariç hiç değişmediği görülmüştür. Aynı şekilde kadılığa ödenen harç miktarları ve gayrimenkullerden alınan yıllık kira miktarları da sabit kaldığı sonucuna ulaşılmıştır.

Anahtar Kelimeler: Osmanlı Devleti, Vakıf, Mektep, Eğitim, Üsküdar.

\section{Income and Expenses of the School Waqfs in the Light of Accounting Records: Example of the Late 18th Century Üskiudar}

\begin{abstract}
Absract
Education services in Ottoman State had been conducted by waqfs until the Maarif Nezareti was established. One of the leading waqfs which provide education services were ottoman elementaryprimary school. In this study, it is aimed to answer such questions from Üsküdar example as "how did those schools finance their services, what kind of attendants worked in them, how much did they pay the staff, what kind of expenses did they have?"

In this study, it is aimed to analyse 5 school waqfs that were active in Uskudar; their incomes and expenses for the period between 1770-1800 (1184-1214 AH) years by using accounting records. The result of the study shows that cash waqfs had increased their main assets in the course time. Besides, it is seen that the amount of total salary paid to the staff was higher than the cost of other items in general. It has also been determined that annual amount paid to the staff were never changed throughout this period, with a few exceptions. Likewise, it is found that the amount of fee paid to Judiciary and annual rent acquired from real estate properties were unchanged.
\end{abstract}

Key Words: Ottoman Empire, Waqf, School, Education, Üsküdar.

* Makalenin yazımında 14-15 Temmuz 2018'de gerçekleştirilen 1. Uluslararası Vakıf Kurumu Sempozyumu'nda sözlü olarak sunduğumuz “İktisadi Açıdan 18. Yüzyıl Sonlarında Üsküdar Mektep Vakıfları" başlıklı tebliğimizden yararlandık.

** Doç. Dr., Sakarya Üniversitesi İlahiyat Fakültesi, suleymankaya@sakarya.edu.tr; Orcid Id: : 00000003-4266-7359

*** Arş. Gör., Sakarya Üniversitesi İslam Ekonomisi ve Finansı ABD, muhammeddurmus@sakarya. edu.tr; Orcid Id: 0000-0003-2468-8551 


\section{Giriş}

Osmanlı toplumsal hayatının ayrılmaz bir parçası olan vakıflar eğitimden sağlığa, altyapıdan bayındırlığa, dini hizmetlerden sosyal hizmetlere, kültürel faaliyetlerden sosyal güvenlik ve dayanışma hizmetlerine kadar pek çok farklı alanda hizmetler icra etmişlerdir Osmanlı Devleti'nin askerî harcamalar dışında bu alanlara doğrudan yatırım yapmadığg, bu gibi hizmetlerin vakıflar vasıtasıyla gerçekleştirildiği bilinen bir durumdur (Yediyıldız, 1982: 5; Tabakoğlu, 1994: 183; Öztürk, 1995: 34; Özcan, 2003:8-9). Vakıflar, zikredilen alanlarda yaptıkları faaliyetler neticesinde hem toplumun refahına hem de devletin ekonomik durumuna önemli katkıda bulundukları ve devletin sırtındaki yükü hafiflettikleri için devlet tarafindan desteklenmiş ve teşvik edilmişlerdir. Pek çok devlet erkânının ve hanım sultanların kurdukları vakıflar bu durumun göstergesidir.

Osmanlı Devleti'nde diğer sosyal ve dini hizmetler gibi 19. yüzyılda Maarif Nezareti kuruluncaya dek askerî ve teknik eğitim veren kurumların haricinde eğitim ve öğretim faaliyetleri de vakıflar aracılığıyla yürütülmüştür (Öztürk, 1995b: 41). Mektep, medrese, darulhadis, darulkurra gibi eğitim kurumlarının her türlü ihtiyacı, buralarda görev yapan kişilerin maaşları, bu kurumlarda eğitim gören öğrencilerin masrafları vakıflar tarafından karşılanmaktaydı (Yüksel, 1990: 241-242; Birol, 2004: 212). Yukarıda zikredilen alanların her birinde faaliyet göstermek için vakıfların bir takım sürekli gelir kaynaklarına ihtiyaç duyacakları aşikârdır. Üsküdar Şer'iyye Sicilleri'nde muhasebe kaydı bulunan vakıfların gelir kalemleri incelendiğinde, bazı vakıfların sahip oldukları nakit sermayelerini işleterek, bazılarının gayrimenkullerini kiraya vererek, bazılarının ise her iki yöntemden gelir elde ettikleri görülmektedir. Vakıflar bu gelirler sayesinde hizmetlerini uzun yıllar sürdürmüşler ve varlıklarını koruyabilmişlerdir.

Osmanlı klasik dönemi süresince sibyan mekteplerine önceleri "muallimhane" daha sonraları ise genellikle "mektep" denilirdi. Mektep vakıfları muallime görev verilmesiyle faaliyetine başlard1. Mektepler, bir külliye içerisinde yer almıyorsa genellikle sokakların kesişme noktalarında ve cami ile mescit çevresinde yer alırlardı. Medreselerden farklı olarak mektepler küçük çocukların kendilerini evlerinde hissetmeleri için genellikle ev mimarisinde yapılırlardı. Mektep vakfiyelerinde, iyilik sahibi, kötülükten uzak duran, çocuk eğitiminde mahir, işini aksatmayan, iffetli ve dindar kimselerin bu mekteplerde hocalık yapmaları şart koşulmaktaydı. Bu mekteplerde okuyan öğrenciler 5-6 yaşlarında eğitime başlar, 3-4 yıl boyunca eğitime devam ederlerdi. Bu süre zarfında öğrenciler ilk önce Kur'an okumayı öğrenirler, sonrasında ise sarf, nahiv, fıkıh, edep, yazı gibi dersler alırlardı. Osmanlı klasik dönemi boyunca bu çizgide devam eden mektepler özellikle Tanzimat sonrası bir takım değişikliklere uğramışlardır (Hızlı, 2008: $1-3)$.

Osmanlı'da hemen hemen her mahallede en az bir mektep bulunmasındaki en önemli faktör, ailelerin çocuklarının okuma ve yazma ile dinin temel kaidelerini öğrenmesi arzusudur. Nitekim bu mektepler genelde Kur'an'1 okutmak, namaz kılmay1, namazda okunacak ayet ve duaları öğretmek ve yazı yazdırmak amacına binaen kurulmaktaydı (Gelişli, 2002: 35-38).

Bu çalışmada, 1184-1214/1770-1800 yılları arasında Üsküdar'da faaliyet gösterip Üsküdar Şer'iyye Sicilleri'nde muhasebe kaydı bulunan bütün mektep vakıflarının gelir kaynakları ve 
gider kalemleri ele alınmaktadır. Zikredilen dönemde Üsküdar'da faaliyet gösterip Üsküdar sicillerinde muhasebe kaydı bulunan yaklaşı 100 vakıf bulunmaktadır. Bu vakıflardan araştırma yapılan üç dönemde de muhasebe kaydı tespit edilebilen 5 mektep vakfı bulunmaktadır. Aşăğda ayrıntısı verilecek bu üç periyotta muhasebesi tespit edilemeyen mektep vakıfları çalışmaya dâhil edilmemiştir. ${ }^{1}$ Çalışmada gelir ve giderleri incelenen vakıfların muhasebe kayıtları, İstanbul Şer’iyye Sicilleri Arşivi Üsküdar Mahkemesi’ndeki (İŞSA Üsküdar Mahkemesi) 488, 513, 525 ve 573 numaralı defterlerde yer almaktadır. Muhasebe defterlerinde; vakfin adı, kurucusu, yeri, muhasebesinin tutulduğu tarih, mütevellisi, varsa nakit sermayesi veya gayrimenkulleri, masraf kalemleri, vazife ücretleri, kiracıları, zimem kayıtları gibi önemli bilgiler yer almaktadır (Durmuş vd. 2017: 197).

Çalışmada muhasebe defterlerinin yanı sıra birincil kaynak olarak vakfiyeler de kullanılmıştır. Beş vakfın vakfiyesi İstanbul Şer'iyye Sicilleri’nde araştırılmış olup üç tanesinin vakfiyesi tespit edilebilmiştir. ${ }^{2}$

488 numaralı defterde yer alan bütün vakıflara ait gelir ve giderler Durmuş tarafindan hazırlanan yüksek lisans tezinde (Durmuş, 2016), 513 ve 525 numaralı defterlerde yer alan vakıfların gelir ve giderleri ise Kaya tarafından hazırlanan doktora tezinde (Kaya, 2007) ele alınmıştır. Ancak bu tezlerde özel olarak mektep vakıfları değil defterlerde yer alan bütün vakıflar bazı yönleriyle incelenmiştir. Bu çalışmada ise, zikredilen çalışmaların 15 y1l sonrasına ait iki y1llık bir periyot daha eklenmiş ve bunun yanı sıra her iki tezde de ayrıntısı hakkında bilgi verilmeyen, sadece adı ve genel olarak gelir-giderleri zikredilen mektep vakıflarının, yıllar boyunca nasıl bir seyir izledikleri, mülkleri, nakit sermayeleri ve gelirlerinde nasıl bir değişiklik olduğu, hangi yıllarda ne tür masraflar yaptıkları, hangi görevliye ne kadar maaş ödedikleri gibi daha ayrıntılı konulara yer verilmiştir.

İncelenen defterlerde muhasebesi yapılan bazı vakıfların mektep vakfı olmamasına rağmen eğitim hizmetlerine yönelik bir takım harcamalar yaptıkları görülmektedir. Bu da göstermektedir ki her ne kadar müstakil olarak mektep vakfı olmasa da bazı vakıflar bu tür hizmetler için de kaynak ayırmışlardır. ${ }^{3}$ Ancak bu çalışmada sadece mektep vakıfları ele alınmaktadır.

Çalışmanın zaman aralı̆̆ı olan üç periyot şöyledir: Birinci periyot 1184-1188/1770-1774 yılları arasındaki 5 yıl, ikinci periyot 1198-1199/1784-1785 y1lları, üçüncü periyot ise 1213-1214/17991800 yıllarıdır. Çalışmanın birinci periyodu 1768'den 1774'e kadar süren Osmanl1-Rus savaşının olduğu dönemi, ikinci periyodu savaştan 10 yıl sonraki dönemi, üçüncü periyodu ise Rusya ve Avusturya'ya karşı girişilen 1787'den 1792'ye kadar süren savaştan 8 yıl sonraki dönemi kapsamaktadır. Çalışmanın hem savaş dönemini hem de savaştan sonraki dönemi kapsaması muka-

1 Üsküdar'da devlet erkânı tarafından kurulan büyük gelirlere sahip vakıflar da bulunmaktadır. Ancak bu vakıfların muhasebeleri Üsküdar kadılığı tarafından tutulmamaktadır. Bu sebeple bu şekilde devlet erkânı tarafından kurulan büyük ölçekli vakıflar da çalışmaya dâhil edilmemiştir. Örneğin Üsküdar'da 18. yüzyılın sonlarında Hacı Selim Ağa tarafından kurulan Mektep ve Kütüphane Vakfı büyük ölçekli vakıflardan biridir (Bardak, 2016).

2 Vakfiyeler tespit edilirken Bilgin Aydın vd. tarafından hazırlanan "İstanbul Şer'iyye Sicilleri Vakfiyeler Kataloğu” adlı kitapta yer alan tablodan yararlanılmıştır. Bk. Bilgin aydın vd., İstanbul Şer’iyye Sicilleri Vakfiyeler Kataloğu, İSAM Yayınları, İstanbul: 2016.

3 İŞSA, Üsküdar Mahkemesi 488, vr. 7a-1, 12b-1, 15b-1, 15b-2, 17a-1, 17a-2, 24a-2. 
yese açısından önem arz etmektedir. Nitekim her iki Rus savaşı da mağlubiyetle sonuçlanmış ve Osmanlı ağır savaş tazminatlarıyla karşı karşıya kalmıştır. Mali bunalım içerisinde olan Osmanlı Devleti bu durumdan kurtulabilmek için 1789 y1lında büyük bir tağşiş gerçekleştirmiş ve kuruşun gümüş içeriği üçte bir oranında azaltılmıştır (Pamuk, 2012: 186). Çalışmada 5 yıllık ilk periyottan 10 y1l ve 25 y1l sonrasına ait verilerin kullanılmasının sebeplerinden biri, bu dönemlerde yapılan tağşişlere bağlı olarak enflasyonun artmasının vakıfların gelir ve giderlerine nasıl bir etkisinin olduğunu tespit edebilmektir.

Muhasebe kayıtlarında, vakıfların nakit sermayeleri ve zimem kayıtları kuruş cinsinden, elde edilen gelirler ve yapılan harcamalar ise akçe cinsinden ifade edilmektedir. Bu çalışmada da muhasebe kayıtlarında olduğu gibi vakıfların gelir ve giderleri akçe cinsinden belirtilmiştir. ${ }^{4}$

Muhasebe kayıtları incelendiğinde vakıfların giderlerinin genelde 2 ana bölüme kaydedildiği görülmektedir. "Mesârif" diye adlandırılan birinci bölümde tamirat, aydınlatma, temizlik, resmi harçlar gibi pek çok farklı alana sarf edilen giderler, "Vezâif” diye adlandırılan ikinci bölümde ise vakfin idari kadrosuna, dini-ilmi hizmetleri yerine getiren görevlilere ve vakıfların temizlik gibi çeşitli ihtiyaçlarını gideren hizmetlilere ödenen maaşlar yer almaktadır.

Çalışmada evvelemirde her bir vakıf ayrı başlıklar altında ele alınacak olup ilgili vakfın, gelir ve giderleri tablolar yardımıyla ortaya koyulacaktır. Sonrasında ise 5 vakıf birbirleriyle mukayese edilecektir.

\section{Hayrettin Çavuş Mahallesi El-Hâc Bedel Mektep ve Kürsü Vakfı}

Hayrettin Çavuş Mahallesi'nde, el-Hâc Bedel ibn İbrahim adlı hayır sahibi tarafindan 4 Zilhicce 1055/21 Ocak 1646 tarihinde kurulmuştur. Hayır sahibi inşa ettiği bu mektebin giderlerinin karşılanması için iki bâb fevkânî beyti, iki bâb sayfiyeyi, taht-pûşu, tahtânî üç bâb odayı, su kuyusunu, bahçeyi ve hâricesini, ekmek firınını müştemîl menzilini de vakfetmiştir. Ancak vâkıf hayatta olduğu müddetçe menzilde kendisinin tasarrufta bulunacağını vakfiyede belirtmiştir (İŞSA, Üsküdar Mahkemesi 203, vr. 27b). Bu sebeple vâkıf hayatta olduğu sürece bu menzilin gelir elde etmek için kiraya verilemediğini söylemek mümkündür.

Vakfın muhasebe kaydı çalışmanın son yılları olan 1213/1799 ve 1214/1800 yıllarında tespit edilemediğinden bu yıllara ait olan gelir ve giderleri tabloya dâhil edilememiştir. Ancak vakfın 1215/1801 yılında muhasebesi yapılmıştır. Buradan hareketle vakfın hala hizmetlerine devam ettiği yani varlığını sürdürdüğü fakat bir dönem muhasebesinin yapılmadığını söylemek mümkündür. ${ }^{5}$ Bu periyottaki durumu göstermesi açısından 1215/1801 y1lına ait veriler tablolara eklenmiştir.

\subsection{Gelirleri}

Sadece gayrimenkullere sahip olan ve bu gayrimenkullerin kiraya verilmesinden gelir elde eden vakfın muhasebe kaydı çalışmanın son iki yılı hariç bütün yıllarda düzenli olarak tutulmuştur. Vakfın ilk 5 yıl gayrimenkullerinin kiraya verilmesinden 11.160 akçe kira geliri ve

4 Çalışmanın zaman aralığı olan dönemde 1 kuruş 120 akçeye denk gelmektedir.

5 Vakfın muhasebe defterleri ve defterlerdeki kayıt numaraları sırasıyla şu şekildedir: İŞSA, Üsküdar Mahkemesi 488, vr. 2b-2, 20a-2, 44b-1, 67b-2, 81b-2; 525, vr. 8b-2, 22a-1; 573, vr. 60a-1. 
önceki seneden kalan fazla miktarı bulunmaktadır. Daha sonraki iki yılda ise vakfın sadece kira geliri elde ettiği aşağıdaki tablodan anlaşılmaktadır.

Vakfın kurulduğu zaman mülkleri içerisinden sadece ekmek firınından kira geliri elde ettiği görülmektedir. Bunun haricinde her hangi bir mülkten kira geliri elde ettiğine dair vakfiyede bir bilgi bulunmamaktadır. Vakfiyede, firının icaresinden elde edilecek gelirin sarf edilmesi öngörülen yerlere ödenecek toplam miktar 6.840 akçe olarak belirtilmiştir. Öyleyse vakfın kuruluşundan yaklaşık bir buçuk asır sonra bir yılda elde etmiş olduğu 11.160 akçe kira gelirinin bu ekmek firınından, hayır sahibinin -hayatta olduğu sürece kendi tasarrufunda olmak üzere- vakfettiği menzilin hayır sahibi vefat ettikten sonra kiraya verilmesinden veya aynı vâkıf tarafından 1076/1665-1666 yılında mütevelli ve talim-i sıbyan için vakfedilen ev ve arsanın kiralanmasından elde edildiği söylenebilir (İŞSA, Üsküdar Mahkemesi 239, vr. 28a-b).

Vakfın gayrimenkullerinde kimlerin kiracı olduğu muhasebe kaydında belirtilmediği için bunlar hakkında yorum yapmak mümkün gözükmemektedir. Muhasebe kaydında vakfın kira geliri sicil-i mahfûzda mukayyed vakf-ı mezbûr müsakkafâtından bir senede hâsıl olan icarât şeklinde kaydedilmiştir.

Tablo 1: Hayrettin Çavuş Mahallesi El-Hâc Bedel Mektep Ve Kürsü Vakfinın Gelirleri (Akçe) (1184-1215/1770-1801)

\begin{tabular}{cccc}
\hline YII & Yıllık Kira Geliri & Önceki Seneden Kalan Miktar & Toplam Gelir \\
\hline 1184 & 11.160 & 6.279 & $\mathbf{1 7 . 4 3 9}$ \\
\hline 1185 & 11.160 & 6.279 & $\mathbf{1 7 . 4 3 9}$ \\
\hline 1186 & 11.160 & 6.909 & $\mathbf{1 8 . 0 6 9}$ \\
\hline 1187 & 11.160 & 6.674 & $\mathbf{1 7 . 8 3 4}$ \\
\hline 1188 & 11.160 & 4.958 & $\mathbf{1 6 . 1 1 8}$ \\
\hline 1198 & 11.160 & - & $\mathbf{1 1 . 1 6 0}$ \\
\hline 1199 & 11.160 & - & $\mathbf{1 1 . 1 6 0}$ \\
\hline 1215 & 11.640 & - & $\mathbf{1 1 . 6 4 0}$ \\
\hline
\end{tabular}

Tabloda da görüldüğü üzere vakfın kira geliri son yıl hariç bütün yıllarda aynı miktarda olmuştur. Ancak ilk beş yıllık periyotta vakfın önceki yıldan kalan gelir fazlası vardır. Aynı fazlalığın beş yıl boyunca biraz artarak bir sonraki yıla devredildiği söylenebilir. Son yılda kira gelirlerindeki 480 akçelik artışın sebebi vakfın yeni bir gayrimenkul satın alıp kiralaması olduğu tahmin edilebilir.

\subsection{Giderleri}

1.2.a. Mesârif: Aşağıdaki tabloda vakfın yıllara göre yapmış olduğu masraf kalemleri ve bu masrafların miktarları yer almaktadır. Vakfın vakfiyesinde yer alan tek masraf kalemi yılda 1.800 akçe olmak üzere vakfedilen menzilin tamir ve meremmetine sarf edilmesi şart koşulan masraftır. Bunun haricindeki masraf kalemleri vakfiyede yer almamaktadır. 
Tablo 2: Hayrettin Çavuş Mahallesi el-Hâc Bedel Mektep ve Kürsü Vakfinın Masrafları (Akçe) (1184-1215/1770-1801)

\begin{tabular}{ccccccccc}
\hline Yıl & $\begin{array}{c}\text { Kömür } \\
\text { Masrafı }\end{array}$ & $\begin{array}{c}\text { Mukâtaa } \\
\text { Kariz }\end{array}$ & $\begin{array}{c}\text { Harc-I } \\
\text { Muhasebe }\end{array}$ & $\begin{array}{c}\text { Kalemiyye } \\
\text { Kâtip }\end{array}$ & $\begin{array}{c}\text { inzariyye, } \\
\text { Kaydiyye }\end{array}$ & $\begin{array}{c}\text { Tamirat, } \\
\text { Mesârif-i } \\
\text { Saire }\end{array}$ & Zayiat & Toplam \\
\hline 1184 & 360 & 180 & 120 & 60 & 30 & 372 & - & $\mathbf{1 . 1 2 2}$ \\
\hline 1185 & 360 & 180 & 120 & 60 & 30 & 1.500 & - & $\mathbf{2 . 2 5 0}$ \\
\hline 1186 & 360 & 180 & 120 & 60 & 30 & 2.365 & - & $\mathbf{3 . 1 1 5}$ \\
\hline 1187 & 360 & 180 & 120 & 60 & 30 & 3.846 & - & $\mathbf{4 . 5 9 6}$ \\
\hline 1188 & 360 & 180 & 120 & 60 & 30 & 1.830 & 1.440 & $\mathbf{4 . 0 2 0}$ \\
\hline 1198 & 360 & - & 120 & 60 & 30 & 1.640 & - & $\mathbf{2 . 2 1 0}$ \\
\hline 1199 & 360 & - & 120 & 60 & 30 & 1.640 & - & $\mathbf{2 . 2 1 0}$ \\
\hline 1215 & 360 & 180 & 120 & 60 & 30 & 1170 & 1.440 & $\mathbf{3 . 3 6 0}$ \\
\hline
\end{tabular}

Tabloda yer alan masraf kalemlerinden biri olan harc-ı muhasebe, vakıfların muhasebelerini tescil ettirmeleri karşılığında kadılığa ödedikleri ücreti; mukâtaa kariz, vakfın kanalizasyon için ödediği mukâtaa ücretini; kalemiyye kâtip, vakıfların muhasebelerinin kayıt işlemlerini yapan görevlilere ödenen ücreti ifade etmektedir. Kaydiyye; muhasebe defterini yazmakla görevli olan kişiye verilen ücret demektir. İhzariyye ise mahkemeye kendiliğinden gelmeyenlerin muhzırlar vasitasıyla getirilmesi sonucunda alınan paradır (Ünal, 2011: 343; Y1lmaz, 2010: 274; Pakalın, 1993: 45).

Tablodan da anlaşıldığı üzere vakıf binaların bazı tamir ihtiyaçları meydana gelmiş ve bu ihtiyaçları gidermek için yapılan masraflar tamirat başlığı altında kaydedilmiştir. Vakıfların hizmet binalarına yaptıkları tamirat masrafı genel kural olarak vazife ücretlerinden önce gelmektedir (Berki, 1940: 239).

Vakfın her yıl çeşitli tamirat masraflarının olduğu muhasebe kaydında yer almaktadır. 1184/1770 yılında yapılan 372 akçe tamirat masrafının ne tamiratı için sarf edildiği bilinmemektedir. 1185/1771 yılında yapılan 1.500 akçe tamirat masrafının ayrıntısı şu şekildedir: 360 akçe nerdüban (merdiven veya basamak) tamirine, 180 akçe mektebin kapısının tamirine, 180 akçe rahle tamirine verilmiş, 240 akçe de ustalara ödenmiştir. 1186 y1lı tamirat masrafı olan 2.365 akçe, mektebin çeşitli tamirat ihtiyaçlarına, çatının aktarılmasına ve sair giderlere sarf olunmuştur. 1187/1773 yılı tamirat masrafı olan 3.846 akçe, çatının aktarılması için alınan kiremit bedelini, mektep tamiratına ve ustalara ödenen ücreti kapsamaktadır. 1188/1774 ve 1215/1801 yıllarında yapılan tamiratın ayrıntısı hakkında ise muhasebe kaydında her hangi bir bilgi yer almamaktadır. 1198/1784 yılında tamirat başlığı altında kaydedilen 1.640 akçe masraf, vakfın hamamının tamirine ve mektep için satın alınan kilime sarf edilmiştir. 1199/1785 yılı 1.640 akçe tamirat masrafı ise mektebin nerdübanı (merdiven, basamak) ve camlarının tamiratı için yapılmıştır.

Tabloda da görüldüğü gibi mütevelli, 1188/1774 ve 1215/1801 yıllarında vakfın gayrimenkullerinde kiracı olanlardan toplamda 1.440'er akçe tahsil edememiş ve bu tahsil edilemeyen 
miktar zayiat olarak muhasebe defterine kaydedilmiştir (Bk. Tablo 2). Çok sık rastlanmasa da örnekte olduğu gibi vakıfların bazen borçlarını tahsil edemediği durumlar meydana gelmektedir.

\section{2.b. Vezâif}

Vakıfların büyüklüğüne göre vakıfta çalışan hizmetli sayısı farklılık arz etmektedir. Eğer vakıf küçükse gerekli olan bütün işleri vakfın mütevellisinin veya birkaç görevlinin yerine getirdiği ve her görevden ayrı ücret aldığı muhasebe kayıtlarından anlaşılmaktadır. ${ }^{6}$ Büyük vakıflarda ise genellikle her görevi yapan kişi farklı olmakla birlikte vâkıfın isteği doğrultusunda bazı kişiler birden fazla görev de icra edebilmektedirler (İŞSA, Üsküdar Mahkemesi 488, vr. 4b-2). Vakıflarda çalışacak görevliler, bu görevlilerin nitelikleri, yapacakları işler ve alacakları maaşlar vakfiyelerde bizzat vakıf kurucuları tarafından açık bir şekilde belirlenmiştir (İŞSA, Rumeli Mahkemesi 2, vr. 2a-2, 4b-1, 5a-1, 13a-1, 21b-1, 48a-2).

Vâkıf, ekmek firınının icareye verilmesinden elde edilen gelirden günlük 7 akçe ( yılda 2.520 akçe) vakfin hocasına, 4 akçe (yılda 1.440 akçe) halifesine, 3 akçe (yılda 1.080 akçe) mütevellisine verilmesini şart koşmuştur (İşSA, Üsküdar Mahkemesi 203, vr. 27b). Vakfiyesinde bu görevliler haricinde bir kimseye ücret ödeneceğine dair her hangi bir bilgi bulunmamaktadır. Ancak aşağıdaki tablodan bu görevlilere ek olarak başka görevlilerin de vakıfta görev yaptığı anlaşılmaktadır (Bk. Tablo 3).

Tablo 3: Hayrettin Çavuş Mahallesi el-Hâc Bedel Mektep ve Kürsü Vakfinın Görevlileri ve Aldıkları Maaşlar (Akçe) (1184-1215/1770-1801)

\begin{tabular}{ccccccccc}
\hline Yıl & Mütevelli & Câbi & Hoca & Şeyh & Nâzır & Kâtip & Halife & Toplam \\
\hline 1184 & 1.080 & 720 & 2.520 & 1.800 & 360 & 360 & 1.440 & $\mathbf{8 . 2 8 0}$ \\
\hline 1185 & 1.080 & 720 & 2.520 & 1.800 & 360 & 360 & 1.440 & $\mathbf{8 . 2 8 0}$ \\
\hline 1186 & 1.080 & 720 & 2.520 & 1.800 & 360 & 360 & 1.440 & $\mathbf{8 . 2 8 0}$ \\
\hline 1187 & 1.080 & 720 & 2.520 & 1.800 & 360 & 360 & 1.440 & $\mathbf{8 . 2 8 0}$ \\
\hline 1188 & 1.080 & 720 & 2.520 & 1.800 & 360 & 360 & 1.440 & $\mathbf{8 . 2 8 0}$ \\
\hline 1198 & 1.080 & 720 & 2.520 & 1.800 & 360 & 360 & 1.440 & $\mathbf{8 . 2 8 0}$ \\
\hline 1199 & 1.080 & 720 & 2.520 & 1.800 & 360 & 360 & 1.440 & $\mathbf{8 . 2 8 0}$ \\
\hline 1215 & 1.080 & 720 & 2.520 & 1.800 & 360 & 360 & 1.440 & $\mathbf{8 . 2 8 0}$ \\
\hline
\end{tabular}

Mütevelli, vakfın işlerini şer’̂̂ hükümler ve vakfiye şartları çerçevesinde idare etmekle (Ünal, 2011: 507; Y1lmaz, 2010: 488; Pakalın, 1993: 640; Berki, 1940: 37); câbi, vakfin her türlü tahsilat işlerini yürütmekle (Ünal, 2011: 136; Pakalın, 1993a: 253); hoca; mektepte sıbyana ders vermekle (Yılmaz, 2010: 250; Pakalın, 1993a: 344); şeyh, irşad eden kimse olarak (Pakalın, 1993c: 346) sıbyana yol göstermekle görevli kimse şeklinde tanımlanabilir. Nâzır,

6 Örneğin Üsküdar'da Kadı Karyesinde bulunan Kethüda Vakfı'nın mütevellisi aynı zamanda vakfın yasinhân, mülkhân, nebehân ve ihlashân görevlerini de icra etmiş ve her görevden ayrı ücret almıştır. (İŞSA, Üsküdar Mahkemesi 488, vr. 1b-1). 
mütevellinin tasarruf ve muamelelerine nezaret etmek ve denetlemekle (Ünal, 2011: 513; Y11maz, 2010: 496; Pakalın, 1993b: 666; Berki, 1940: 37); kâtip, vakfın kayıtlarını tutmakla (Ünal, 2011: 387); halife, mekteplerde talebelerin derslerini müzakere ve anlayamadıkları yerleri onlara anlatmakla yani hocaya yardım etmekle (Ünal, 2011: 287; Pakalın, 1993a: 709; Yediyıldız, 1983: 57) görevli olan kimsedir. El-Hâc Bedel Mektep Vakfı muhasebe defterinde, 7 farklı görevi 5 görevlinin icra ettiği, vakfın mütevellisinin bu görevinin yanında câbilik ve hocalık da yaptığı bilgisi yer almaktadır. Vakfın mütevellisi Ali Efendi mütevellilikten yıllık 1.080 akçe, hocalıktan 2.520 akçe ve câbilikten 720 akçe, toplam 4.320 akçe maaş almıştır. Diğer görevliler ise sadece tek bir görevden maaş almışlardır. Görevlilerin maaşlarında 30 yıllık bir süreçte her hangi bir değişiklik olmamıştır.

\section{2.c. Gelir-Gider Dengesi}

Tablo 4: Hayrettin Çavuş Mahallesi el-Hâc Bedel Mektep ve Kürsü Vakfinın Gelir-Gider Dengesi (Akçe) (1184-1215/1770-1801)

\begin{tabular}{cccc}
\hline YIl & Toplam Gelir & Toplam Gider & Gelir-Gider Dengesi \\
\hline 1184 & 17.439 & 9.402 & $\mathbf{8 . 0 3 7}$ \\
\hline 1185 & 17.439 & 10.530 & $\mathbf{6 . 9 0 9}$ \\
\hline 1186 & 18.069 & 11.395 & $\mathbf{6 . 6 7 4}$ \\
\hline 1187 & 17.834 & 12.876 & $\mathbf{4 . 9 5 8}$ \\
\hline 1188 & 16.118 & 12.320 & $\mathbf{3 . 7 9 8}$ \\
\hline 1198 & 11.160 & 10.490 & $\mathbf{6 7 0}$ \\
\hline 1199 & 11.160 & 10.490 & $\mathbf{6 7 0}$ \\
\hline 1215 & 11.640 & 11.640 & $\mathbf{0}$ \\
\hline
\end{tabular}

Tabloda, vakfin her yıl gelirinin giderinden fazla olduğu gözükmektedir. Ancak burada vakfın ilk 5 yıldaki toplam gelirinin içerisinde önceki seneden kalan fazlalıklarının da olduğuna dikkat edilmelidir. Bu durumda vakfin 11.160 akçe olan asıl geliri 1187/1773 ve 1188/1774 yıllarında giderinden daha az olmuş yani vakfın cari açı̆̆ı meydana gelmiştir. Fakat önceki seneden kalan fazlalıklar hesaba dâhil edilince vakfın bütçe fazlasının meydana geldiği anlaşılmaktadır. Fazla kalan miktarlar muhasebe kaydında ifade edildiği üzere vakfın mütevellisinin elinde muhafaza edilmiştir.

1198/1784 ve 1199/1785 y1lları muhasebe kaydında mütevellinin vakıftan 23.998 akçe alacağı olduğu yazmaktadır. Önceki yıllarda vakfın mülklerinden birinin önemli miktarda tamir masrafı çıktığı, bundan dolayı mütevelliye borçlanıldığı şeklinde bir yorum yapmak mümkündür. 1215/1801 yılı kaydında vakfın, mütevelli yerine tayin olunan câbiye yalnız 3.120 akçe borcunun olduğu belirtilmektedir.

\section{2. Çengel Karyesi El-Hâc Süleyman Ağa Mektebi Vakfı}

Çengel karyesinde yer alan bu mektep 1166/1752 yılında el-Hâc Süleyman ibn Osman Ağa tarafından inşa ettirilmiştir. Vakfin 1188/1774 yılı muhasebe kaydı tespit edilemediği için bu y1la ait kısımlar boş bırakılmıştır.?

7 Vakfın muhasebe defterleri ve defterlerdeki kayıt numaraları sırasıyla şu şekildedir: İşSA. Üsküdar Mahkemesi 488, vr. 5b-1, 35a-3, 52a-2, 69b-1; 525, vr. 8a-2, 26b-1; 573, vr. 22a-1, 38b-1. 


\subsection{Gelirleri}

Süleyman Ağa'nın bina eylediği mektep vakfi, hem nakit sermayesini işletmekten hem de sahip olduğu gayrimenkulleri kiralamaktan gelir elde etmektedir. Vakfın kurucusu Süleyman Ağa vakfa gelir sağlaması için iki kepenk bir bab kasap dükkânını, dükkânın üstündeki odayı ve işletilmek üzere 310 kuruşu vakfetmiştir. Vakfiyede kasap dükkânının her ay 50 pareye (150 akçe) kiraya verileceği, 310 kuruşun ise \%15 ribh oranıla istirbah ve istiğlal olunacağı bilgisi yer almaktadır (İŞSA, Üsküdar Mahkemesi 435, vr. 83b).

Vakfın gayrimenkullerinin bir kısmı icare-i vahide ile bir kısmı ise icareteyn ile kiraya verilmiştir. İcare-i vahide, vakıf akarların kısa bir süreliğine ve tek bir kira bedeli karşılığında kiraya verilmesini (Akgündüz, 2000: 388); icareteyn akdi ise adından anlaşılacağı üzere vakıf akarların biri muaccele diğeri müeccele olmak üzere çift kira bedeliyle ve kaydı hayat şartıyla kiraya verilmesini ifade etmektedir (Kaya, 2014: 114). Vakfın nakit sermayesi istiğlâl ve muamele-i şer'iyye ile işletilmiştir. Kısaca bu akitleri tanımlayacak olursak; muamele- $i$ şer 'iyye, borç alırken tahakkuk edecek olan fazlalığın satım akdinden kaynaklanmış olmasını sağlamak için yapılan hile-i şer'iyyedir (Kaya, 2007: 14). Istiğlâl ise Mecelle'de şöyle tanımlanmıştır: "Bâyi' bir malı isticar etmek üzere vefâen bey' etmektir" (Berki 1982, Mecelle, md. 119). Tanımdan da anlaşılacağı üzere bey' bi’l-vefa akdinin kiralama şartıyla yapılmasına bey“ bi’l-istiğlâl denilmektedir. İstiğlal akdi şöyle gerçekleştirilmektedir; bir yıl vadeyle 100 kuruş borca ihtiyaç duyan kişi, borç verecek olan kişiye 100 kuruş değerinde bir mülkünü parasını geri ödediğinde geri almak ve bu bir yıl boyunca bu mülkte kiracı olmak şartıyla satmaktadır. Böylece borçlu ihtiyacı olan 100 kuruşu temin edecek, alacaklı ise borcun vadesi gelinceye kadar bu mülkten kira geliri elde edecektir. Aşağıdaki tabloda vakfın yıllara göre elde ettiği murabaha ve kira gelirleri yer almaktadır.

Tablo 5: Çengel Karyesi El-Hâc Süleyman Ağa Mektebi Vakfinın Gelirleri (1184-1214/17701800)

\begin{tabular}{cccccc}
\hline Yıl & $\begin{array}{c}\text { Sermaye Miktarı } \\
\text { (Kuruş) }\end{array}$ & $\begin{array}{c}\text { Murabaha Geliri } \\
\text { (Akçe) }\end{array}$ & $\begin{array}{c}\text { Kira Geliri } \\
\text { (Akçe) }\end{array}$ & $\begin{array}{c}\text { Önceki Seneden } \\
\text { Kalan Fazla Gelir } \\
\text { (Akç) }\end{array}$ & $\begin{array}{c}\text { Toplam Gelir } \\
\text { (Akçe) }\end{array}$ \\
\hline 1184 & 607,5 & 10.920 & 8.400 & - & $\mathbf{1 9 . 3 2 0}$ \\
\hline 1185 & 887,5 & 14.166 & 1.800 & - & $\mathbf{1 5 . 9 6 6}$ \\
\hline 1186 & 818,5 & 14.166 & 1.800 & - & $\mathbf{1 5 . 9 6 6}$ \\
\hline 1187 & 818,5 & 14.166 & 1.800 & - & $\mathbf{1 5 . 9 6 6}$ \\
\hline 1188 & - & - & - & - & - \\
\hline 1198 & 819 & 12.384 & 2.520 & - & $\mathbf{1 4 . 9 0 4}$ \\
\hline 1199 & 900 & 14.742 & 2.520 & - & $\mathbf{1 7 . 2 6 2}$ \\
\hline 1213 & 1.237 & 19.404 & 5.040 & 32.738 & $\mathbf{5 7 . 1 8 2}$ \\
\hline 1214 & 1.337 & 19.404 & 5.040 & 18.444 & $\mathbf{4 2 . 8 8 8}$ \\
\hline
\end{tabular}

Vakfın 1184/1770 yılı muhasebe kaydında kasap ve bakkal olmak üzere iki dükkândan toplam 8.400 akçe kira elde edildiği ancak sonraki dört yılda sadece kasap dükkânından 1.800 akçe 
kira geliri elde ettiği yazmaktadır. ${ }^{8}$ Bu durumun sebebi vakfın sahip olduğu bakkal dükkânını 1184/1770 y1lı kirası olan 6.600 akçeyi tahsil ettikten sonra satmasıdır. Zira 1184/1770 yı11 kaydında Horosto adlı zimmiden 55 kuruş (6.600 akçe) kira geliri alındığ 1 ve bakkal dükkânının satım bedeli olan 200 kuruşun da vakfın asl-1 malına eklendiği bilgisi yer almaktadır. Böylece 607,5 kuruş olan asl-1 malın 1185/1771 yılındaki artışının sebebinin bakkal dükkânından elde edilen 200 kuruşun ve önceki seneden fazla kalan 79,5 kuruşun eklenmesi olduğunu söylemek mümkündür.

1185/1771 y1lı kaydında önceki seneden kalan fazlalık vakfın asl-1 malına eklendikten sonra 1186/1772 yılı asl-1 malı 918,5 kuruşa yükselmiştir. Ancak 1186/1772 yılında vakfin 100 kuruşu gayr-i merbûh olmuş ve gayr-i merbûh olan bu 100 kuruş muhasebe kaydında asl-1 mal olarak zikredilmemiştir. Çalışmada da muhasebe kaydında olduğu gibi gayr-i merbûh olan 100 kuruş asl-1 mala dâhil edilmemiş bu sebeple tabloda 1186/1772 y1lı asl-1 malı olarak 818,5 kuruş yazılııştır. 1186/1772 yılından 1199/1785 yılına kadar geçen sürede vakfın asl-1 malında bir değişiklik olmamış ancak 1199/1785 yılında önceki senelerden kalan 9.825 akçe gelir fazlasının vakfın nakit sermayesine eklenmesi ile nakit sermaye 900 kuruşa yükselmiştir. 1199/1785 y1lı muhasebe kaydında, fazla kalan 5.158 akçenin zimemden tahsil edildikten sonra nakit sermayeye ekleneceği bilgisi yer almaktadır. Bunun yanı sıra vakfın 1198/1784 ve 1199/1785 yılları kayıtlarında, kasap dükkânı ve mektep odasından bir yılda toplam 2.520 akçe kira gelirinin olduğu belirtilmektedir. Bu durumda vakfin bünyesinde bulunan odalardan birini kiraladığı ve bu odadan y1llık 740 akçe kira geliri elde ettiği şeklinde bir yorum yapmak mümkündür.

1213/1799 ve 1214/1800 yıllarına gelindiğinde vakfın asl-1 malında önemli bir artış olduğu gözükmektedir. Bununla beraber vakfın kasap dükkânından ve bir odadan elde ettiği kira miktarında da bir artış meydana gelmiş vakfın yıllık toplam kira miktarı 2.520 akçeden 5.040 akçeye yükselmiştir. Bunun sebebi aradaki 15 yıl içerisinde enflasyon sebebiyle akçenin satın alma gücünün düşmesi sonucu kira bedelinin ecr-i misile çıkarılması olabilir.

Vakfın 1213/1799 yılında 32.738 akçe, 1214/1800 yılında ise 18.444 akçe gibi yüksek miktarlarda önceki seneden kalan fazlası bulunmaktadır. 1213/1799 yılında fazla kalan gelirden 12.000 akçe vakfın asl-1 malına eklendiği için 1214/1800 yılı asl-1 malı 1.337 kuruşa yükselmiştir. Vakfın kuruluş yılı olan 1166/1752 yılında nakit sermayesi 310 kuruşken 48 yıl sonrası 1214/1800 yılında 1.337 kuruşa yükselmiştir. Bu artışın en önemli kaynağının vakfın 48 y1llık süreçte çoğunlukla gelir fazlası vermesi ve bu fazlalıkların sermayeye eklenmesi olduğu anlaşılmaktadır. Ancak vakfın gayrimenkul satıp nakit sermayeye dönme tercihinde bulunması da ihtimal dâhilindedir. Osmanlı Devleti’nin maddi açıdan en zor dönemini yaşadığı bu yıllarda vakfın nakit sermayesini 4 kattan fazla artırması dikkat çekici bir durumdur.

\subsection{Gider Kalemleri}

\section{2.a. Mesârif}

8 Vakfiyede, vakfın sadece kasap dükkânı olduğu ifade edilmekle beraber ileriki yıllarda vakfın bir bakkal dükkânı satın aldığı ve bu dükkândan da kira geliri elde ettiği anlaşılmaktadır. 
Tablo 6: Çengel Karyesi El-Hâc Süleyman Ağa Mektebi Vakfinın Masrafları (Akçe) (11841214/1770-1800)

\begin{tabular}{|c|c|c|c|c|c|c|c|c|c|c|c|c|c|c|}
\hline$\equiv$ & 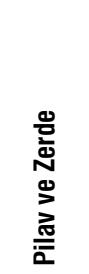 & : : & 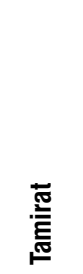 & 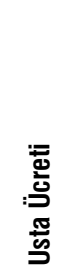 & 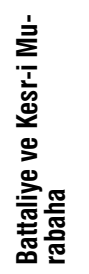 & 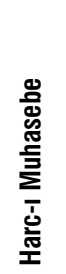 & 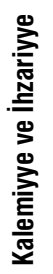 & 紊 & $\frac{\mathbb{N}}{\stackrel{N}{N}}$ & 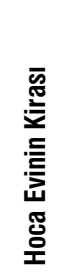 & 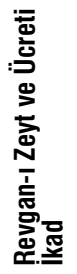 & 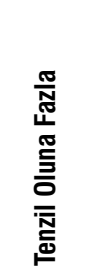 & 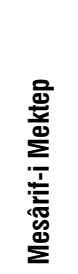 & $\begin{array}{l}\text { 틍 } \\
\text { 흥 } \\
\text { 을 }\end{array}$ \\
\hline 1184 & 960 & 180 & 1.380 & 3.600 & 4.560 & 120 & 60 & - & - & - & - & - & - & 10.860 \\
\hline 1185 & - & - & - & - & - & 120 & 60 & - & 10.800 & - & - & - & - & 10.980 \\
\hline 1186 & 1.800 & 540 & 900 & - & - & 120 & 60 & - & - & - & - & - & - & 3.420 \\
\hline 1187 & 2.400 & 540 & 1.560 & - & 1.920 & 120 & 60 & - & - & 720 & - & - & - & 7.320 \\
\hline 1188 & - & - & - & - & - & - & - & - & - & - & - & - & - & - \\
\hline 1198 & 1.200 & 360 & - & - & 1.440 & 120 & 60 & 30 & - & - & 363 & - & - & 3.573 \\
\hline 1199 & 1.200 & 360 & - & - & 900 & 120 & 60 & 30 & - & - & 360 & - & 2.354 & 5.384 \\
\hline 1213 & 2.040 & 1.200 & - & - & 3.000 & 120 & 60 & 30 & - & - & - & 14.288 & - & 20.738 \\
\hline 1214 & 2.040 & 1.300 & - & - & 3.000 & 120 & 60 & 30 & - & - & - & - & - & 6.550 \\
\hline
\end{tabular}

Vakfın vakfiyesinde belirtilen masrafları şöyledir: Senede bir defa 360 akçe ile sıbyana kömür alınacak, karye dışında Çakaldağı adlı mahallede vâkıfın ihya ettiği musallanın tamiratı için 360 akçe sarf olunacak, sıbyana pilav ve zerde tabhı için 720 akçe verilecek ve muhasebe harc1 için 120 akçe ödenecektir. Geri kalan 9 kuruş ise ihtiyaç varsa mektebin tamirine sarf edilecek yoksa asl-1 mala eklenecektir (İŞSA, Üsküdar Mahkemesi 435, vr. 83b). Tabloda bu masraf kalemleri haricinde başka masraf kalemleri olduğu gözükmektedir. Bu masrafların zaman geçtikçe ihtiyaç hâsıl olduğu için yapıldığı bu durumun da vakfiye şartlarına aykırı bir durum olmadığı söylenebilir.

Tablodan da anlaşılacağı üzere vakfın masrafları toplamı her yıl farklılık göstermiştir. Vakfin masrafları arasından vâkıfın şartı üzerine yılda bir defa sıbyana yani mektepte okuyan öğrencilere verilmek üzere "pilav ve zerde" masrafı gözükmektedir. 1185/1771 yılında vakfın zayiatı çok olduğu için talebelere bu yıl pilav ve zerde verilmemiş bunun yanında halifeye ödenen yıllık 1.080 akçe de ödenmemiştir. Zayiatın sebebi vakıftan borç alan iki kişinin aldığı borçları ve bu borçlardan beklenen kârı ödememeleridir.

Tabloda masraf olarak yer alan battâliye; vakfın elde etmesi gereken karın tamamını elde edememesi sonucunda kârından zarar etmesi manasına gelmektedir. Vakfın 8 yıl içerisinde önemli bir miktarda battâliye ve kesr-i murâbahası olduğu gözükmektedir. Bu durum vakfin tahsilat işlerinin iyi bir şekilde yapılamadığının göstergesidir.

Tabloda dikkat çeken masraflardan biri de vakfın hocasının oturduğu evin kirasıdır. Vakıf, hocalık görevini yapan Abdullah Efendi’nin 1187/1773 yılında oturduğu evin kirasını karşılamıştır. Ancak diğer yıllarda böyle bir masraf kalemi bulunmamaktadır. 
Tabloda yer alan "tamirat masrafı" ise vakfin gayrimenkullerinin ve hizmet binalarının ihtiyaç duyduğu tamirata ödenen ücreti göstermektedir. 1184/1770 y1lında mektep ve kasap dükkânı için 1.380 akçe, 1186/1772 yılında kasap dükkânı ve namazgâh için 900 akçe, 1187/1773 y1lında ise 1.560 akçe tamirat masrafi yapılmıştır. "Usta ücreti” olarak kaydettiğimiz masraf ise vakfın kiraya verdiği dükkâna yapılan tamiratın ustalık ücretini ifade etmektedir.

Kadılığa ödenen "harc-1 muhasebe" ve "kalemiyye ve ihzariyye" masraflarının her sene düzenli olarak ödendiği, kaydiyye masrafının ise sadece çalışmanın son yıllarında ödendiği görülmektedir.

Vakfin 1198/1784 ve 1199/1785 yıllarındaki giderleri arasında mektebin keniflerinin aydınlatılması için "revgan-1 zeyt ve ücret-i ikad" masrafı bulunmaktadır. Bu ücret önceki yıllarda yer almamaktadır. 1199/1785 yılı kaydında mesârif-i mektep adı altında kaydedilen gider kaleminin içerisinde ne tür masrafların olduğu hakkında her hangi bir bilgi bulunmamaktadır.

Tabloda dikkat çeken bir diğer masraf kalemi ise 1213/1799 yılı masraf kalemleri arasında yer alan "tenzil olunan fazla" başlığı altında kaydedilen masraftır. Önceki mütevelli, vakfın 14.288 akçe fazlasının olduğunu beyan etmiş, ancak yapılan tetkikler sonucunda vakfin bu miktarda bir fazlasının mevcut ve mümkün olmadı̆̆ı anlaşılmış ve yapılan tashih neticesinde muhasebe kaydında fazla olarak yazılan bu miktar, vakfın kaydından düşülmüştür.

\section{2.b. Vezâif}

Vâkıf, vakfiyesinde elde edilen gelirlerden günlük 9 akçe vakfın hocası olan Mustafa Efendi’ye, günlük 3 akçe halife olan Molla Ali’ye ve günlük 1 akçe de mütevelli olarak kendine verilmesini şart koşmuştur. Vâkıf, tevliyet görevini hayatta olduğu müddetçe kendisinin yerine getirmesini vefatından sonra ise Türbedar Ahmet Efendi'nin mütevelli olmasını, o da vefat ettikten sonra vakfın halifelik görevini icra eden Molla Ali'nin mütevelli olmasını, onun da vefatından sonra batnen ba'de batnin evladlarının mütevelli olmasını istemiştir. (İŞSA, Üsküdar Mahkemesi 435, vr. 83b). Ayrıca vakfiyede, vâkıf tarafindan atanan halife ve hocadan sonra bu görevlerin karye ahalisi ve nazır marifetiyle mütedeyyin olarak bilinen kimselere verilmesi şart koşulmuştur.

Tablo 7: Çengel Karyesi El-Hâc Süleyman Ă̆a Mektebi Vakfinın Görevlileri ve Aldıkları Maaşlar (Akçe) (1184-1214/1770-1800)

\begin{tabular}{ccccccc}
\hline Yıl & Mütevelli & Halife & Kâtip & Kaimmakam & Hoca & Toplam \\
\hline 1184 & 360 & 1.080 & - & - & 3.240 & $\mathbf{4 . 6 8 0}$ \\
\hline 1185 & 360 & - & - & - & - & $\mathbf{3 6 0}$ \\
\hline 1186 & 360 & 1.080 & - & - & 4.680 & $\mathbf{6 . 1 2 0}$ \\
\hline 1187 & 360 & 1.080 & - & - & 3.240 & $\mathbf{4 . 6 8 0}$ \\
\hline 1188 & - & - & - & - & - & - \\
\hline 1198 & 360 & - & - & 2.400 & 3.600 & $\mathbf{6 . 3 6 0}$ \\
\hline 1199 & 360 & - & 360 & 2.400 & 3.600 & $\mathbf{6 . 7 2 0}$ \\
\hline 1213 & 2.400 & - & - & - & 3.600 & $\mathbf{6 . 0 0 0}$ \\
\hline 1214 & 2.400 & - & - & - & 3.600 & $\mathbf{6 . 0 0 0}$ \\
\hline
\end{tabular}


Vakfın mütevellisi Molla Ali vakfiyede de belirtildiği üzere ilk dört yılda aynı zamanda vakfin halifelik görevini de yerine getirmiştir. Molla Ali tevliyet görevinden yıllık 360 akçe, halifelik görevinden ise 1.080 akçe maaş almaktadır. Vakfın hocası Abdullah Efendi’nin 1185/1771 yılında maaş almadığı görülmektedir. Ancak 1186/1772 yılında hocaya ödenen 4.680 akçenin içerisinde hocaya önceki senede ödenemeyen ve sulh yoluyla bu y1l takdir edilen 1.440 akçe de dâhildir. 1186/1772 yılı muhasebe kaydında vazife ücretlerinin yer aldığı bölümde "sene-i sabıkada mektep hocasına bi tariki sulh" başlığı altında 1.440 akçe ödendiği bilgisi yer almaktadır. 1185/1771 y1lında maaş alamayan hoca 1186/1772 yılında vakıfla anlaşmak suretiyle maaş miktarında indirim yaparak 1.440 akçe almıştır. 1185/1771 yılında halifelik görevi için ücret ödenmemesi ve hocalık görevi için de 1.440 akçe ödenmesinin sebebinin vakfın önemli sayılabilecek bir miktarda zayiat vermesi olduğu tahmin edilebilir.

1198/1784 ve 1199/1785 yıllarında vakfa İsmail Ağa ibn Hâc Medmed, kaimmakam mütevelli olarak nasb olunmuştur. Kaimmakam, bazı konularda mütevelliye ait işleri görmek üzere kadı tarafından görevlendirilen kişi anlamına gelmektedir (Yılmaz, 2010: 304). 1198/1784 ve 1199/1785 yıllarında vakfa, niçin kaimmakam mütevellinin tayin olunduğu hakkında muhasebe kayitlarında her hangi bir malumat bulunmamaktadır. Fakat bu durumun geçici olduğu diğer y1llarda kaimmakam görevi için ücret ödenmediğinden anlaşılmaktadır. kaimmakam mütevelli bu görevinden yıllık 2.400 akçe maaş almıştır. Daha önceki yıllarda mütevelli olan kişi bu görevinin yanında halifelik görevini de yerine getirmekte ve her iki görevden de maaş almaktayd1. Ancak 1198/1784 ve 1199/1785 y1llarında halifelik görevi için maaş ödenmemiş bunun yerine kaimmakamlık için ödenmiştir. Diğer yıllardan farklı olarak 1199/1785 yılında vakfın görevlileri arasına kâtibin eklendiği görülmektedir. 1213/1799 ve 1214/1800 yıllarında ise vakıftan sadece mütevelli ve muallimin maaş aldığı, diğer görevliler hakkında her hangi bir bilgi bulunmadığı görülmektedir.

\section{2.c. Gelir-Gider Dengesi}

Tablo 8: Çengel Karyesi El-Hâc Süleyman Ă̆a Mektebi Vakfinın Gelir-Gider Dengesi (Akçe) (1184-1214/1770-1800)

\begin{tabular}{cccc}
\hline YII & Toplam Gelir & Toplam Gider & Gelir-Gider Dengesi \\
\hline 1184 & 19.320 & 15.540 & $\mathbf{3 . 7 8 0}$ \\
\hline 1185 & 15.966 & 10.980 & $\mathbf{4 . 9 8 6}$ \\
\hline 1186 & 15.966 & 7.290 & $\mathbf{8 . 6 7 6}$ \\
\hline 1187 & 15.966 & 12.000 & $\mathbf{3 . 9 6 6}$ \\
\hline 1188 & - & - & - \\
\hline 1198 & 14.904 & 9.933 & $\mathbf{4 . 9 7 1}$ \\
\hline 1199 & 17.262 & 12.104 & $\mathbf{5 . 1 5 8}$ \\
\hline 1213 & 57.182 & 26.738 & $\mathbf{3 0 . 4 4 4}$ \\
\hline 1214 & 42.888 & 12.550 & $\mathbf{3 0 . 3 3 8}$ \\
\hline
\end{tabular}


Tablodan da anlaşılacağı üzere vakfın geliri üç yıl aynı miktarda diğer yıllarda ise farklı miktarlarda olmuştur. Vakfın 1184/1770 y1lında diğer y1llara göre fazla gelir elde etmesinin sebebi daha önce de ifade ettiğimiz üzere vakfın kasap ve bakkal olmak üzere iki dükkândan kira geliri elde etmesidir. Bu yıldan sonraki yıllarda sadece kasap dükkânından kira geliri elde edildiği için diğer yıllarda vakfın daha az miktarda kira geliri olmuştur. Vakfın her yıl gelir fazlalığı olmakla birlikte son iki yılda çok yüksek miktarlarda gelir fazlası olmuştur. Bu durumun sebebi vakfın gelir fazlalıklarından tahsil edilenlerin asl-i mala eklenmesi ve bunun neticesinde daha yüksek miktarda murabaha geliri elde etmesi ve tahsil edilemeyenlerin ise sonraki senenin muhasebesinin gelir kısmına "önceki seneden kalan fazla" başlığı altında dâhil edilmesidir.

1213/1799 yılında vakfın 30.404 akçe fazlası olmuş ve bu fazlanın 12.000 akçesi vakfin nakit sermayesine eklenmiştir. Vakfın geri kalan gelir fazlası olan 18.444 akçenin zimemden tahsil edildikten sonra vakfın nakit sermayesine ekleneceği bilgisi muhasebe kaydında yer almaktadır. 1214/1800 yılında ise vakfın 30.448 akçe fazlası olmuş ve bu fazlanın 9.120 akçesi vakfin nakit sermayesine eklenmiştir. Geri kalan 21.218 akçenin zimemden tahsil edildikten sonra vakfin nakit sermayesine ekleneceği bilgisi muhasebe kaydında yer almaktadır.

\section{Evliya Hâce Mahallesi Fatıma Hatun Mektep Vakfı}

Evliya Hâce Mahallesi’ndeki bu mektep vakfının kurucusu adından da anlaşıldığı üzere Fatıma Hatun'dur. Fatıma Hatun gibi pek çok kadının vakıf kurması veya vakıflardan borç para alması onların Osmanlı toplumsal ve iktisadi hayatında aktif olduklarının bir göstergesidir. ${ }^{9}$

\subsection{Gelir Kaynakları}

Tablo 9: Evliya Hâce Mahallesi Fatıma Hatun Mektep Vakfinın Gelirleri (11841214/1770-1800)

\begin{tabular}{cccc}
\hline Yıl & Sermaye Miktarı (Kuruş) & Murabaha Geliri (Akçe) & Toplam Gelir (Akçe) \\
\hline 1184 & 150 & 2.700 & $\mathbf{2 . 7 0 0}$ \\
\hline 1185 & 150 & 2.700 & $\mathbf{2 . 7 0 0}$ \\
\hline 1186 & 150 & 2.700 & $\mathbf{2 . 7 0 0}$ \\
\hline 1187 & 150 & 2.700 & $\mathbf{2 . 7 0 0}$ \\
\hline 1188 & 150 & 2.700 & $\mathbf{2 . 7 0 0}$ \\
\hline 1198 & 150 & 2.700 & $\mathbf{2 . 7 0 0}$ \\
\hline 1199 & 150 & 2.700 & $\mathbf{2 . 7 0 0}$ \\
\hline 1213 & 150 & 2.700 & $\mathbf{2 . 7 0 0}$ \\
\hline 1214 & 150 & 2.700 &
\end{tabular}

Evliya Hâce Mahallesi Fatıma Hatun Mektebi sadece nakit sermayesini işletmekten gelir elde etmektedir. Vakfın nakit sermayesi istiğlâl ve muamele-i şer'iyye akitlerinin her ikisiyle de işletilmektedir. Vakfin her yıl nakit sermayesini işletmekten 2.700 akçe geliri olmuştur. Yani vakfın bu tarihler boyunca sermayesinde ve elde ettiği gelirde her hangi bir değişiklik meydana gelmemiştir.

9 Vakfın muhasebe defterleri ve defterlerdeki kayıt numaraları sırasıyla şu şekildedir: İşSA, Üsküdar Mahkemesi 488, vr. 11a-3, 27b-2, 52b-3, 65a-3, 75a-3; 525, vr. 9b-2, 23a-2; 573, vr. 25b-2, 34a-2. 


\subsection{Gider Kalemleri}

\section{2.a. Mesârif}

Tablo 10: Evliya Hâce Mahallesi Fatıma Hatun Mektep Vakfinın Masrafları (Akçe) (11841214/1770-1800)

\begin{tabular}{ccccc}
\hline Yıl & Harc-ı Muhasebe & Kalemiyye Kâtip & ihzariyye & Toplam \\
\hline 1184 & 120 & 60 & 30 & $\mathbf{2 1 0}$ \\
\hline 1185 & 120 & 60 & 30 & $\mathbf{2 1 0}$ \\
\hline 1186 & 120 & 60 & 30 & $\mathbf{2 1 0}$ \\
\hline 1187 & 120 & 60 & 30 & $\mathbf{2 1 0}$ \\
\hline 1188 & 120 & 60 & 30 & $\mathbf{2 1 0}$ \\
\hline 1198 & 120 & 60 & 30 & $\mathbf{2 1 0}$ \\
\hline 1199 & 120 & 60 & 30 & $\mathbf{2 1 0}$ \\
\hline 1213 & 120 & 60 & 30 & $\mathbf{2 1 0}$ \\
\hline 1214 & 120 & 60 & 30 & $\mathbf{2 1 0}$ \\
\hline
\end{tabular}

Tablodan da anlaşıldığı üzere vakfın masraf kalemleri sadece kadılığa ödenen ücretlerden oluşmaktadır. Tabloda yer alan tarihler boyunca vakfın ödediği harçların miktarında da her hangi bir değişiklik olmadığı görülmektedir.

\section{2.b. Vezâif}

Tablo 11: Evliya Hâce Mahallesi Fatıma Hatun Mektep Vakfinın Görevlileri ve Aldıkları Maaşlar (Akçe) (1184-1214/1770-1800)

\begin{tabular}{ccccc}
\hline Yıl & Mütevelli & Hoca & ihlashân & Toplam \\
\hline 1184 & 360 & 1.440 & 360 & $\mathbf{2 . 1 6 0}$ \\
\hline 1185 & 360 & 1.440 & 360 & $\mathbf{2 . 1 6 0}$ \\
\hline 1186 & 360 & 1.440 & 360 & $\mathbf{2 . 1 6 0}$ \\
\hline 1187 & 360 & 1.440 & 360 & $\mathbf{2 . 1 6 0}$ \\
\hline 1188 & 360 & 1.440 & 360 & $\mathbf{2 . 1 6 0}$ \\
\hline 1198 & 360 & 1.440 & 360 & $\mathbf{2 . 1 6 0}$ \\
\hline 1199 & 360 & 1.440 & 360 & $\mathbf{2 . 1 6 0}$ \\
\hline 1213 & 360 & 1.440 & 360 & $\mathbf{2 . 1 6 0}$ \\
\hline 1214 & 360 & 1.440 & 360 & $\mathbf{2 . 1 6 0}$ \\
\hline
\end{tabular}

Tablodan da anlaşılacağı üzere vakıfta üç farklı vazife için maaş ödenmiştir. Vakfın bütün bu görevlerini yerine getiren kimse İmam Osman Efendi'dir. Osman Efendi bu görevlerinin haricinde vâkıfın şartı üzerine vakfin gelir fazlası olursa bu fazlalığı da almaktadır. Osman Efendi'ye ödenen maaş miktarı 30 yıl boyunca sabit kalmıştır. 


\section{2.c. Gelir-Gider Dengesi}

Tablo 12: Evliya Hâce Mahallesi Fatıma Hatun Mektep Vakfinın Gelir-Gider Dengesi (Akçe) (1184-1214/1770-1800)

\begin{tabular}{cccc}
\hline YIl & Toplam Gelir & Toplam Gider & Gelir-Gider Dengesi \\
\hline 1184 & 2.700 & 2.370 & $\mathbf{3 3 0}$ \\
\hline 1185 & 2.700 & 2.370 & $\mathbf{3 3 0}$ \\
\hline 1186 & 2.700 & 2.370 & $\mathbf{3 3 0}$ \\
\hline 1187 & 2.700 & 2.370 & $\mathbf{3 3 0}$ \\
\hline 1188 & 2.700 & 2.370 & $\mathbf{3 3 0}$ \\
\hline 1198 & 2.700 & 2.370 & $\mathbf{3 3 0}$ \\
\hline 1199 & 2.700 & 2.370 & $\mathbf{3 3 0}$ \\
\hline 1213 & 2.700 & 2.370 & $\mathbf{3 3 0}$ \\
\hline 1214 & 2.700 & 2.370 & $\mathbf{3 3 0}$ \\
\hline
\end{tabular}

Vakfın bütün yıllarda yıllık ödediği toplam maaş miktarı 2.160 akçe, yaptığı masraflar toplam1 210 akçe toplam gideri ise 2.370 akçedir. Yıllık geliri 2.700 akçe olan vakfin 330 akçe gelir fazlası vardır. Muhasebe kaydında yer alan bilgiye göre bu gelir fazlası vâkıfın şartı üzere vakfın İmam'ına tahsis edilmiştir. Böylece vakfın gelir-gider dengesi eşitlenmiştir. Vakfın gelir fazlasının belli bir cihete tahsis edildiği bu tür vakıflarda nakit sermaye sabit kalmaktadır. Düşük de olsa enflasyon olması hasebiyle bu durumun uzun vadede vakfın sermayesinin satın alma gücü itibariyle erimesine yol açtığ söylenebilir.

\section{Hamza Fakih Mahallesi Kâtip Hüseyin Efendi Mektep Vakfı}

Vakıf, hayır sahibi Kâtip Hüseyin Çelebi bin Behram tarafından 1004/1590 yılının evâil-i Cemaziyelevvel'inde Hamza Fakih Mahallesi'nde kurulmuştur. Vâkıf, iki kayıkhane ve 55.000 rayiç akçe vakfetmiş, akarların kiraya verilmesinden ve nakit sermayenin istirbah ve istiğlal olunmasından elde edilen gelir ile vakfın hizmetlerinin yerine getirilmesini şart koşmuştur (İSSA, Üsküdar Mahkemesi 92, vr. 37a). Vakfın 1187/1773 yılındaki muhasebe kaydına ulaş1lmamış bu sebeple o yılın gelir ve gider kısımları boş bırakılmıştır. ${ }^{10}$

\subsection{Gelirleri}

Tablo 13: Hamza Fakih Mahallesi Kâtip Hüseyin Efendi Mektep Vakfinın Gelirleri (11841214/1770-1800)

\begin{tabular}{ccccc}
\hline Yıl & $\begin{array}{c}\text { Sermaye Miktarı } \\
\text { (Kuruş) }\end{array}$ & $\begin{array}{c}\text { Murabaha Geliri } \\
\text { (Akçe) }\end{array}$ & Mukâtaa Geliri (Akçe) & Toplam Gelir (Akçe) \\
\hline 1184 & 955 & 17.190 & 240 & $\mathbf{1 7 . 4 3 0}$ \\
\hline 1185 & 955 & 17.190 & 240 & $\mathbf{1 7 . 4 3 0}$ \\
\hline 1186 & 955 & 17.190 & 240 & $\mathbf{1 7 . 4 3 0}$ \\
\hline 1187 & - & - & - & - \\
\hline 1188 & 955 & 17.190 & 240 & $\mathbf{1 7 . 4 3 0}$ \\
\hline 1198 & 991,5 & 17.847 & 240 & $\mathbf{1 8 . 0 8 7}$ \\
\hline 1199 & 1011,5 & 17.847 & 240 & $\mathbf{1 8 . 0 8 7}$ \\
\hline 1213 & 1051,5 & 14.400 & 240 & $\mathbf{1 4 . 6 4 0}$ \\
\hline 1214 & 1051,5 & 15.660 & 240 & $\mathbf{1 5 . 9 0 0}$ \\
\hline
\end{tabular}

10 Vakfın muhasebe defterleri ve defterlerdeki kayıt numaraları sırasıyla şu şekildedir: İŞSA., Üsküdar Mahkemesi 488, vr. 13a-2, 27b-3, 47a-1, 71b-1; 513, vr. 72a-1, 525, vr. 24a-1; 573, vr. 13a-2, 37a-1. 
Kâtip Hüseyin Efendi’nin bina eylediği mektep vakfının hem nakit sermayesi olan 55.000 akçeyi işletmekten murabaha geliri hem de bir menzilin arsasından elde ettiği mukâtaa geliri bulunmaktadır. Mukataa; vakıf arazinin, şahsına ait bina inşa etmek veya ağaç dikmek isteyen bir kimseye kiralanması anlamına gelir (bk. Kaya, 2014: 37-51). Dolayısıyla Kâtip Hüseyin Efendi vakfına ait boş arazide kendi mülkü olmak üzere menzil inşa eden şahsın arazinin kira bedeli olarak vakfa 240 akçe ödediği söylenebilir. Bu gelir vâkıf tarafından mektep hocasına şart koşulmuştur.

Vakfin 1199/1785, 1213/1799 ve 1214/1800 yıllarında nakit sermayesinin bir miktarı gayr-i merbûhtur. Bu sebeple vakfin murabaha geliri olması gereken miktardan daha düşük olmuştur. 1198/1784 y1lında 991,5 kuruş olan vakfın sermayesinin 1199/1785 y1lında 1011,5 kuruşa yükselmesinin sebebi vakıfta çalışan görevlilerin maaşlarından 20 kuruşu vakfetmeleridir. Aynı durum 1199/1785 y1lı için de geçerlidir. ${ }^{11}$

\subsection{Giderleri}

\section{2.a. Mesârif}

Tablo 14: Hamza Fakih Mahallesi Kâtip Hüseyin Efendi Mektep Vakfinın Masrafları (Akçe) (1184-1214/1770-1800)

\begin{tabular}{ccccccccc}
\hline Yıl & Bedeli Avarız & Kömür & $\begin{array}{c}\text { Menzil } \\
\text { Mukâtaası }\end{array}$ & $\begin{array}{c}\text { Harc-ı } \\
\text { Muhasebe }\end{array}$ & $\begin{array}{c}\text { Kalemiyye } \\
\text { Kâtip }\end{array}$ & $\begin{array}{c}\text { ihzariyye, } \\
\text { Kaydiyye }\end{array}$ & $\begin{array}{c}\text { Mektep } \\
\text { Tamiratı }\end{array}$ & Toplam \\
\hline 1184 & 120 & 360 & 240 & 120 & 60 & 30 & 600 & $\mathbf{1 . 5 3 0}$ \\
\hline 1185 & 120 & 360 & 240 & 120 & 60 & 30 & 960 & $\mathbf{1 . 8 9 0}$ \\
\hline 1186 & 120 & 360 & 240 & 120 & 60 & 30 & $\mathbf{9 3 0}$ \\
\hline 1187 & - & - & - & - & - & - & - & - \\
\hline 1188 & 120 & 360 & 240 & 120 & 60 & 30 & 1.200 & $\mathbf{2 . 1 3 0}$ \\
\hline 1198 & 120 & 360 & 240 & 120 & 60 & 30 & 1.200 & $\mathbf{2 . 1 3 0}$ \\
\hline 1199 & 120 & 360 & 240 & 120 & 60 & 30 & - & $\mathbf{9 3 0}$ \\
\hline 1213 & 120 & 360 & 240 & 120 & 60 & 30 & - & $\mathbf{9 3 0}$ \\
\hline 1214 & 120 & 360 & 240 & 120 & 60 & 30 & - & $\mathbf{9 3 0}$ \\
\hline
\end{tabular}

Vakfın giderleri arasında yer alan avarız bedeli dikkat çekmektedir. Vâkıf tarafından mahalledeki fukaranın avarızlarının ödenmesi için vakfın gelirlerinden 120 akçe ayrılması şart koşulmuştur. Tabloda da görüldüğü üzere vakfın tamirat masrafı hariç diğer masrafları bütün yıllarda eşit olmuştur. Masraflar arasında hocanın ikamet ettiği menzil mukataası için ödenen 240 akçe

11 Vakfın görevlileri maaşlarından 20 kuruşu vakfın nakit sermayesine eklenmek üzere hibe etmişlerdir. Böylece 1200 yılında vakfın nakit sermayesi 1031,5 kuruşa yükselmiştir (İŞSA., Üsküdar Mahkemesi 525, vr. 39a-2). 
dikkat çekmektedir. Vâkıfın şartı üzere vakfın sahip olduğu 240 akçe kira geliri hocaya şart koşulduğu için bu parayla hocanın menzil mukataası ödenmiştir.

\section{2.b. Vezâîf}

Vakfiyede, her gün ikindi namazından sonra Kur'an' dan cüz ve Fatiha, Yasin, İhlas surelerini okuyacak görevlilerin her birine günlük 1,5 akçe, mütevelliye 2 akçe, câbiye 1 akçe ve kâtibe de 4 akçe verilmesi şart koşulmuştur. Geri kalan paranın ise cüzhânlarla vakıf kurucusunun evladı arasında taksim edilmesi istenmiştir (İŞSA, Üsküdar Mahkemesi 92, vr. 37a). Ancak aşağıdaki tabloda da görüldüğü üzere vakıfta hayır sahibinin vakfiyede belirttiği görevlilerden farklı görevliler de bulunmaktadır.

Tablo 15: Hamza Fakih Mahallesi Kâtip Hüseyin Efendi Mektep Vakfinın Görevlileri ve Aldıkları Maaşlar (Akçe) (1184-1214/1770-1800)

\begin{tabular}{cccccccccc}
\hline Yıl & Hoca & Halife & Mütevelli & Kâtip & Câbi & Yasinhân & $\begin{array}{c}\text { Müseb- } \\
\text { bihler }\end{array}$ & Âbkeş & Toplam \\
\hline 1184 & 1.800 & 1.080 & 2.160 & 1.440 & 1.080 & 720 & 6.120 & 360 & $\mathbf{1 4 . 7 6 0}$ \\
\hline 1185 & 1.800 & 1.080 & 2.160 & 1.440 & 1.080 & 720 & 6.120 & 360 & $\mathbf{1 4 . 7 6 0}$ \\
\hline 1186 & 1.800 & 1.080 & 2.160 & 1.440 & 1.080 & 720 & 6.120 & 360 & $\mathbf{1 4 . 7 6 0}$ \\
\hline 1187 & - & - & - & - & - & - & - & - & - \\
\hline 1188 & 1.800 & 1.080 & 2.160 & 1.440 & 1.080 & 720 & 6.120 & 360 & $\mathbf{1 4 . 7 6 0}$ \\
\hline 1198 & 1.800 & 1.080 & 2.160 & 1.440 & 1.080 & 720 & 6.120 & 360 & $\mathbf{1 4 . 7 6 0}$ \\
\hline 1199 & 1.800 & 1.080 & 2.160 & 1.440 & 1.080 & 720 & 6.120 & 360 & $\mathbf{1 4 . 7 6 0}$ \\
\hline 1213 & 1.800 & 1.080 & 2.160 & 1.440 & 1.080 & 720 & 6.120 & 360 & $\mathbf{1 4 . 7 6 0}$ \\
\hline 1214 & 1.800 & 1.080 & 2.160 & 1.440 & 1.080 & 720 & 6.120 & 360 & $\mathbf{1 4 . 7 6 0}$ \\
\hline
\end{tabular}

Bazı görevliler birden fazla görevde çalışmış ve her bir görevden ayrı maaş almışlardır. Vakfın hocası, bu görevinden yıllık 1.800 akçe, müsebbihlik görevinden 360 akçe, Yasinhânlık görevinden 360 akçe ve âbkeşlik görevinden 360 akçe olmak üzere toplam 2.880 akçe maaş almıştır. Müsebbih, vâkıf tarafından tesbih çekmekle görevlendirilen; Yasinhân, Yasin Suresi okumakla görevlendirilen; âbkeş ise vakıfların su ihtiyacını karşılamak üzere kuyu ve çeşmelerden su temin etmekle görevlendirilen kimsedir (Ünal, 2011: 5).

Halife, halifelik görevinden y1llık 1.080 akçe, Yasinhânlıktan 360 akçe ve müsebbihlikten 360 akçe toplamda 1.800 akçe maaş almıştır. Mütevelli, tevliyetten yıllık 2.160 akçe ve müsebbihlikten 360 akçe olmak üzere toplamda 2.520 akçe maaş almıştır. Vakfın câbisi, cibayetten y1llık 1.080 akçe ve müsebbihlikten 360 akçe toplamda 1.440 akçe maaş almıştır. Kâtip ise kitabetten yıllık 1.440 akçe ve müsebbihlikten 360 akçe toplamda 1.800 akçe maaş almıştır. 12 farklı kişi de müsebbihlik görevinden yıllık 360'ar akçeden olmak üzere toplam 4.320 akçe maaş almıştır. Çalışmanın bütün yıllarında vazifelilere aynı ücret ödenmiş olduğu tablodan anlaşılmaktadır. 


\section{2.c. Gelir-Gider Dengesi}

Tablo 16: Hamza Fakih Mahallesi Kâtip Hüseyin Efendi Mektep Vakfinin Gelir-Gider Dengesi (Akçe) (1184-1214/1770-1800)

\begin{tabular}{cccc}
\hline YII & Toplam Gelir & Toplam Gider & Gelir-Gider Dengesi \\
\hline 1184 & 17.430 & 16.290 & $\mathbf{1 . 1 4 0}$ \\
\hline 1185 & 17.430 & 16.650 & $\mathbf{7 8 0}$ \\
\hline 1186 & 17.430 & 15.690 & $\mathbf{1 . 7 4 0}$ \\
\hline 1187 & - & - & - \\
\hline 1188 & 17.430 & 16.890 & $\mathbf{5 4 0}$ \\
\hline 1198 & 18.087 & 16.890 & $\mathbf{1 . 1 9 7}$ \\
\hline 1199 & 18.087 & 15.690 & $\mathbf{2 . 3 9 7}$ \\
\hline 1213 & 14.640 & 15.690 & $\mathbf{- 1 . 0 5 0}$ \\
\hline 1214 & 15.900 & 15.690 & $\mathbf{2 1 0}$ \\
\hline
\end{tabular}

Vakfın 1213/1799 yılı hariç her yıl geliri giderinden fazla olmuş ancak bu gelir fazlalıkları 1184/1770 ile 1188/1774 yılları arasında hala zimem-i nasda olup henüz tahsil edilemediği için vakfın nakit sermayesine eklenememiştir. Muhasebe kaydında, fazla kalan bu miktarların tahsil edildikten sonra nakit sermayeye ekleneceği bilgisi yer almaktadır. Dolayısıyla bu beş yıllık süreçte vakfın nakit sermayesi 955 kuruşta sabit kalmıştır. 1198/1784 yılına gelindiğinde sermaye 991,5 kuruşa çıkmıştır. 1198/1784 yılından kalan 1.197 akçe ve önceki sene muhasebesinden kalan 2.520 akçe ki toplam 3.717 akçe fazlalığın her hangi bir arızi masraf çıkması halinde harcanmak üzere mütevellinin elinde ihtiyat akçesi olarak saklandığı bilgisi muhasebe kaydına not düşülmüştür. 1199/1785 yılından kalan 2.397 akçe ile önceki seneden kalan 3.717 akçe ki toplam 6.114 akçe zimemden tahsil edildikten sonra vakfin bir sonraki y1l nakit sermayesine ekleneceği bilgisi muhasebe kaydında yer almaktadır. 1213/1799 yılında vakfın geliri giderini karşılayamamış vakıf 1.050 akçe açık vermiş ancak mütevelli vakfa borç vererek bu açığı kapatmıştır. Bunun sonucunda mütevellinin bu seneden 1.050 akçe önceki senelerden 20.790 akçe toplam 21.840 akçe vakıftan alacağı olmuştur. Mütevelliye olan bu borcun nereden kaynaklandığı bilinmemekle beraber muhasebe kaydında vakfa nema hâsıl olduğu zaman mütevelliye olan borcun ödeneceği bilgisi yer almaktadır. 1214/1800 yılında fazla kalan miktar mütevelliye verilmiş ve kalan borç miktarı 21.630 akçeye düşmüştür.

\section{Tenbel Hâc Mehmed Mahallesi'nde Hâc İsmail'in Mektep Ve Mülhakatı Vakfı}

Üsküdar'da Tenbel Mahallesi'nde Karakadı Alauddin Efendi Camisinin çevresinde Seyyid el-Hac İsmail'in bina eylediği mektep vakfının 1188/1774 yılındaki muhasebe kaydına ulaşılamadığı için tablolarda bu yıla ait yerler boş bırakılmıştır. Vakfın 1198/1784 ve 1199/1785 yılı muhasebe kayıtları birlikte tutulduğu için gelir ve giderleri ikiye bölünmek suretiyle, 1213/1799 ve 1214/1800 yılları kayıtları ise 1215/1801 yılında 4 yıllık tutulduğu için gelir ve giderleri dörde bölünmek suretiyle tablolara yerleştirilmiştir. ${ }^{12}$

12 Vakfın muhasebe defterleri ve defterlerdeki kayıt numaraları sırasıyla şu şekildedir: İŞSA, Üsküdar Mahkemesi 488, vr. 17b-1, 31b-1, 51b-1, 63b-2; 525, vr. 27b-1, 28b-2; 573, vr. 48b-1. 
Vakfin muhasebe kaydı incelendiğinde Karakadı Alauddin Efendi Camisinin çevresinde yer alan Hâc İsmail'in bina eylediği mektep vakfının mülhakatı yani ilaveleri olan Rahime Hatun ve Hatice Hatun vakıflarının nakit sermayelerinin de bu vakfın nakit sermayesine eklendiği gözükmektedir. Nitekim Rahime Hatun vakfının asl-1 mal1 300 kuruş, Hatice Hatun'un vakfının asl-1 malı ise 50 kuruş olduğu muhasebe kaydında belirtilmiştir. Vakıf hem nakit sermayesini işletmekten murabaha geliri hem de sahip olduğu bir menzilden kira geliri elde etmektedir.

\subsection{Gelir Kaynakları}

Tablo 17: Tenbel Hâc Mehmed Mahallesi’nde Hâc İsmail Mektep ve Mülhakatı Vakfinın Gelirleri (1184-1214/1770-1800)

\begin{tabular}{ccccc}
\hline Yıl & $\begin{array}{c}\text { Sermaye Miktarı } \\
\text { (Kuruş) }\end{array}$ & $\begin{array}{c}\text { Murabaha Geliri } \\
\text { (Akçe) }\end{array}$ & Mukâtaa Geliri (Akçe) & Toplam Gelir (Akçe) \\
\hline 1184 & 1.094 & 14.657 & 360 & $\mathbf{1 5 . 0 1 7}$ \\
\hline 1185 & 1.094 & 14.292 & 360 & $\mathbf{1 4 . 6 5 2}$ \\
\hline 1186 & 1.094 & 15.786 & 360 & $\mathbf{1 6 . 1 4 6}$ \\
\hline 1187 & $\mathbf{1 . 0 9 4}$ & $\mathbf{1 5 . 7 8 6}$ & $\mathbf{3 6 0}$ & 16.146 \\
\hline 1188 & - & - & - & - \\
\hline 1198 & 877 & 11.655 & 360 & $\mathbf{1 2 . 0 1 5}$ \\
\hline 1199 & 877 & 11.655 & 360 & $\mathbf{1 2 . 0 1 5}$ \\
\hline 1213 & 1.054 & 10.500 & 360 & $\mathbf{1 0 . 8 6 0}$ \\
\hline 1214 & 1.054 & 10.500 & 360 & $\mathbf{1 0 . 8 6 0}$ \\
\hline
\end{tabular}

Tablodan da anlaşıldığı üzere vakfın hem murabaha hem de kira geliri vardır. Muhasebe kaydından vakfın nakit sermayesinin bir kısmının muamele-i şer'iyye bir kısmının ise istiğlâl ile işletildiği anlaşılmaktadır. Vakfın nakit sermayesinin aynı miktarda olduğu yıllarda farklı murabaha geliri elde etmesinin sebebi vakfın nakit sermayesinin tamamının işletilememesidir. Vakfın ilk dört yılda, eski mütevelli olan Arpacı Ömer zimmetinde bulunan 300 kuruşu, tahsil edilmesi mümkün olmayan alacak durumundadır. Bundan dolayı vakfın ilk iki yılda nakit sermayesinden ancak 794 kuruşu murabahaya verilebilmiş ve bu miktar üzerinden gelir elde edilmiştir. 1186/1772 yılında vakfın önceki senelerden kalan fazlası ve mütevellinin vakfa hibe ettiği miktar vakfın nakit sermayesine eklenmiş böylece vakfın merbûh olan sermayesi 877 kuruşa yükselmiştir. 1198/1784 ve 1199/1785 yıllarında vakfın nakit sermayesinin 877 kuruş şeklinde kaydedilmesine bakılarak artık Arpacı Ömer zimmetinde gayr-i merbûh olan 300 kuruşun nakit sermayeden sayılmadığı, sadece merbûh olan sermayenin zikredildiği söylenebilir. 1213/1799 ve 1214/1800 yıllarında da vakfin 1.054 kuruşu olmasına rağmen sadece 700 kuruşu merbûh olup bu miktar üzerinden murabaha geliri elde edilmiştir.

Vakfın bir menzilden elde ettiği kira geliri ise tüm y1llarda sabittir. Yıllık 360 akçe bir evin kirası içi çok düşük bir miktar olmasından hareketle evin icareteyn ile kiraya verildiği, 360 akçenin de yıllık müeccele olduğu söylenebilir.

\subsection{Giderleri}

\section{2.a. Mesârif}


Tablo 18: Tenbel Hâc Mehmed Mahallesi'nde Hâc İsmail Mektep ve Mülhakatı Vakfinın Masrafları (Akçe) (1184-1214/1770-1800)

\begin{tabular}{|c|c|c|c|c|c|c|c|c|c|c|}
\hline $\bar{\Sigma}$ & 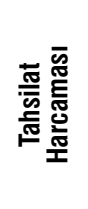 & 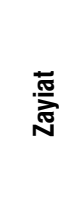 & : & $\begin{array}{l}\text { 옳 } \\
\text { :을 }\end{array}$ & 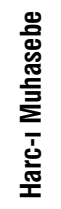 & 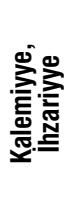 & 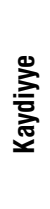 & 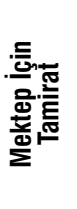 & 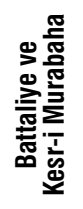 & $\begin{array}{l}\text { 틈 } \\
\frac{\text { 음 }}{2}\end{array}$ \\
\hline 1184 & 4.695 & 2.700 & 720 & 51 & 300 & 180 & - & - & - & 8.646 \\
\hline 1185 & - & - & 720 & 45 & 300 & 180 & - & 180 & - & 1.425 \\
\hline 1186 & - & - & 720 & 30 & 300 & 180 & - & 960 & - & 2.190 \\
\hline 1187 & - & - & 720 & - & 180 & 120 & - & 480 & - & 1.500 \\
\hline 1188 & - & - & - & - & - & - & - & - & - & - \\
\hline 1198 & - & - & - & - & 180 & 90 & 45 & - & 1.120 & 1.435 \\
\hline 1199 & - & - & - & - & 180 & 90 & 45 & - & 1.120 & 1.435 \\
\hline 1213 & - & - & - & - & 180 & 90 & 60 & - & - & 330 \\
\hline 1214 & - & - & - & - & 180 & 90 & 60 & - & - & 330 \\
\hline
\end{tabular}

Vakıf 1184/1770 yılında önceki mütevellisi Arpacı Ömer zimmetinde olan borcun tahsili için 4.695 akçe harcamıştır. Kadılığa ödenen muhasebe harcının önceki vakıfların ödedikleri miktara göre yüksek olmasının sebebi Rahime ve Hatice Hatun vakıflarının muhasebe harçlarının da bu miktarın içinde olmasıdır. Vakıfların birleştikleri halde 1187/1773 yılına kadar ayrı ayrı harç ücreti ödedikleri muhasebe kaydından anlaşılmaktadır. Bu durum ihzariyye ve kaydiyye masrafi için de geçerlidir. Vakfın çeşitli tamirat masraflarının olduğu tablodan anlaşılmaktadır. Ancak bu tamirat için harcanan paraların nerelere sarf edildiği yani neyin tamiratı için kullanıldığı hakkında her hangi bir malumata sahip değiliz. Vakfın 1198/1784 ve 1199/1785 yıllarında borçlulardan alması gereken kârları tam olarak tahsil edememesi sebebiyle battaliye ve kesr-i murabaha giderinin olduğu anlaşılmaktadır. 1213/1799 ve 1214/1800 yıllarında vakıf, sadece kadılığa ödenen resmi harçları ödemiş başka masraf yapmamıştır.

\section{2.b. Vezâif}

Tablo 19: Tenbel Hâc Mehmed Mahallesi'nde Hâc İsmail Mektep ve Mülhakatı Vakfinın Görevlileri ve Aldıkları Maaşlar (Akçe) (1184-1214/1770-1800)

\begin{tabular}{cccccccccc}
\hline Yıl & Mütevelli & Hoca & Kâtip & Câbi & Halife & Yasinhân & íhlashân & Âbkeş & Toplam \\
\hline 1184 & 1.440 & 4.320 & 720 & 720 & 1.440 & 720 & 360 & 360 & $\mathbf{1 0 . 0 8 0}$ \\
\hline 1185 & 1.440 & 4.320 & 720 & 720 & 1.440 & 720 & 360 & 360 & $\mathbf{1 0 . 0 8 0}$ \\
\hline 1186 & 1.440 & 4.320 & 720 & 720 & 1.440 & 720 & 360 & 360 & $\mathbf{1 0 . 0 8 0}$ \\
\hline 1187 & 1.440 & 4.320 & 720 & 720 & 1.440 & 720 & 360 & 360 & $\mathbf{1 0 . 0 8 0}$ \\
\hline 1188 & - & - & - & - & - & - & - & - & - \\
\hline 1198 & 1.440 & 4.320 & 720 & 720 & 1.440 & 720 & 360 & 360 & $\mathbf{1 0 . 0 8 0}$ \\
\hline 1199 & 1.440 & 4.320 & 720 & 720 & 1.440 & 720 & 360 & 360 & $\mathbf{1 0 . 0 8 0}$ \\
\hline 1213 & 1.440 & 4.320 & 720 & 720 & 1.800 & 720 & 360 & 360 & $\mathbf{1 0 . 4 4 0}$ \\
\hline 1214 & 1.440 & 4.320 & 720 & 720 & 1.800 & 720 & 360 & 360 & $\mathbf{1 0 . 4 4 0}$ \\
\hline
\end{tabular}


Vakıf 8 farklı görev için 5 kişiye maaş ödemesi yapmıştır. Vakfın hocası bu görevden yıllık 4.320 akçe ve Yasin suresini okumaktan 720 akçe toplam 5.040 akçe maaş almıştır. Yine mektepte hocanın yardımcısı olarak görev yapan halife bu görevinden yıllık 1.440 akçe ve İhlas suresini okumaktan 360 akçe toplamda 1.800 akçe maaş almıştır. Vakfın hem kâtibi hem de câbisi olan Hüseyin Efendi ise her iki görevden de yıllık 720'şer akçe maaş almıştır. Vakfin mütevellisi vakıftan yıllık 1.440 akçe, vakfa su getirmekle görevli olan âbkeş ise 360 akçe maaş almıştır. 1213 ve 1214 yılları muhasebe kayıtlarında hocaya ödenen günlük 12 akçeden 4 y1lda 14.440 akçe maaş ödendiği yazmaktadır. Ancak günlük 12 akçeden dört yılda ödenmesi gereken miktar 17.280 akçedir. Kayıtta yanlış yazıldığ için gerekli düzeltme yapılarak hocaya ödenen yıllık maaş önceki yıllarda olduğu gibi 4.320 akçe olarak tabloya yazılmıştır.

Halife hariç vakıfta çalışan görevlilerin maaşlarının miktarında 30 yıllık süre zarfında her hangi bir değişiklik meydana gelmemiştir. Ancak halifenin maaşı önceki yılların hepsinde 1.440 akçeyken 1213/1799 ve 1214/1800 yıllarında 1.800 akçeye yükselmiştir. Diğer görevlilerin maaşları sabit kalmışken halifenin maaşının niçin arttığı hakkında muhasebe kaydında her hangi bir bilgi olmadığı için yorum yapmak mümkün gözükmemektedir.

Vazifelilere ödenen maaş miktarlarının 360 ve katları olması dikkat çekmektedir. Bu durumun ücretlerin günlük olarak düşünülmesinden kaynaklandığını söylemek mümkündür. Vakfiyelerde de genellikle günlük ücret tercih edilmiştir.

\section{2.c. Gelir-Gider Dengesi}

Tablo 20: Tenbel Hâc Mehmed Mahallesi'nde Hâc İsmail Mektep ve Mülhakatı Vakfinın Gelir-Gider Dengesi (Akçe) (1184-1214/1770-1800)

\begin{tabular}{cccc}
\hline Yıl & Toplam Gelir & Toplam Gider & Gelir-Gider Dengesi \\
\hline 1184 & 14.657 & 18.726 & $-\mathbf{4 . 0 6 9}$ \\
\hline 1185 & 14.652 & 11.505 & $\mathbf{3 . 1 4 7}$ \\
\hline 1186 & 16.146 & 12.270 & $\mathbf{3 . 8 7 6}$ \\
\hline 1187 & 16.146 & 11.850 & $\mathbf{4 . 2 9 6}$ \\
\hline 1188 & - & - & - \\
\hline 1198 & 12.015 & 11.515 & $\mathbf{5 0 0}$ \\
\hline 1199 & 12.015 & 11.515 & $\mathbf{5 0 0}$ \\
\hline 1213 & 10.860 & 10.770 & $\mathbf{9 0}$ \\
\hline 1214 & 10.860 & 10.770 & $\mathbf{9 0}$ \\
\hline
\end{tabular}

Tablodan anlaşıldığı üzere vakfin sadece 1184/1770 yılında 4.069 akçe bütçe açığı, diğer yıllarda ise farklı miktarlarda gelir fazlası olmuştur. Vakfın 1184/1770 yılında bütçe açığı vermesinin sebebi vakfın eski mütevellisinin elinde bulunun vakıf malın tahsili için yüksek miktarda harcama yapılmasıdır. Ancak vakfın 1183/1769 yılında 5.754 akçe gelir fazlası olduğu için bu açık kapatılabilmiştir. Böylece vakfın 1.685 akçe gelir fazlası olmuştur.

\section{Mektep Vakıflarının Mukayesesi}

Bu başlıkta ilk olarak gelir ve giderleri ayrıntılı bir şekilde ele alınan 5 mektep vakfının toplam ortalama gelir ve giderleri mukayese edilecek, gelir ve giderlerinin nasıl bir seyir izlediği 
ortaya koyulacaktır. Sonrasında vakıflarda çalışan eğitim görevlilerinin aldıkları ortalama maaş miktarlarının vakıfların ortalama giderleri arasındaki oranı tespit edilecektir.

Tablo 21: Vakıfların Ortalama Gelir ve Giderlerinin Mukayesesi (Akçe) (1184-1214/17701800)

\begin{tabular}{lccccccc}
\hline \multicolumn{1}{c}{ Vakfın Adı } & $\begin{array}{c}\text { Ort. } \\
\text { Murabaha } \\
\text { Geliri }\end{array}$ & $\begin{array}{c}\text { Ort. Kira } \\
\text { Geliri }\end{array}$ & $\begin{array}{c}\text { Ort. Toplam } \\
\text { Gelir }\end{array}$ & $\begin{array}{c}\text { Ort. } \\
\text { Mesârif }\end{array}$ & Ort. Vezâif & $\begin{array}{c}\text { Ort. Toplam } \\
\text { Gider }\end{array}$ & $\begin{array}{c}\text { Gelir-Gider } \\
\text { Dengesi }\end{array}$ \\
\hline Hâc Bedel Vakfı & - & 11.160 & 11.160 & 2.789 & 8.280 & 11.069 & 91 \\
\hline Hâc Süleyman Vakfı & 14.919 & 2.790 & 17.709 & 6.854 & 5.115 & 11.969 & 5.740 \\
\hline Fatıma Hatun Vakfı & 2.700 & - & 2.700 & 210 & 2.160 & 2.370 & 330 \\
\hline Kâtip Hüseyin Vakfı & 16.814 & 240 & 17.054 & 1.425 & 14.760 & 16.185 & 869 \\
\hline Hâc İsmail Vakfı & 13.103 & 360 & 13.463 & 2.161 & 10.170 & 12.331 & 1.132 \\
\hline Toplam & $\mathbf{4 7 . 5 3 6}$ & $\mathbf{1 4 . 5 5 0}$ & $\mathbf{6 2 . 0 8 6}$ & $\mathbf{1 3 . 4 3 9}$ & $\mathbf{4 0 . 4 8 5}$ & $\mathbf{5 3 . 9 2 4}$ & $\mathbf{8 . 1 6 2}$ \\
\hline
\end{tabular}

Hâc Bedel Vakfı sadece kira geliri, Fatıma Hatun Vakfı sadece murabaha geliri elde ederken diğer vakıflar hem kira hem de murabaha geliri elde etmektedirler. Vakıfların bütçeleri dikkate alındığında Fatıma Hatun Vakfı'nın ortalama yıllık 2.700 akçe gelirle en küçük ölçekli mektep vakfı olduğu görülmektedir. Gelirleri en yüksek vakıflar Hâc Süleyman Vakfı ve Kâtip Hüseyin Vakfı'nın olup birbirlerine yakın büyüklükte oldukları söylenebilir.

Hâc Süleyman Vakfı hariç diğer vakıfların hepsinde ortalama vezâif miktarı, mesârif miktarından daha yüksektir. Vakıfların vezâif giderlerinin mesârif giderlerinden genel itibariyle çok yüksek olması vakıfların önemli bir istihdam kaynağı olduklarının göstergesidir. Zira bu beş vakfın, görevlilerine 9 yılda ödedikleri ortalama vezâif miktarlarının toplamı 40.395 akçe iken, yaptıkları ortalama masraf miktarlarının toplamı 13.439 akçedir.

Vakıfların ortalama murabaha gelirleri toplamı 47.536 akçe iken ortalama kira gelirleri toplamı 14.550 akçedir. Buradan da anlaşıldığı üzere vakıfların murabaha gelirleri kira gelirlerinin 3 katından fazladır. Öyleyse vakıfların hizmetlerinin finanse edilmesinde murabaha gelirlerinin kira gelirlerine oranla daha önemli katkısının olduğunu söylemek mümkündür.

Tabloda da görüldüğüu üzere vakıfların ortalama gelirleri ortalama giderlerinden fazladır. $\mathrm{Bu}$ sonuç vakıfların iyi yönetildiklerinin bir göstergesi olması hasebiyle önem arz etmektedir. Osmanlı Devleti'nde vakıf kurumunun yüzyıllar boyunca gelişerek varlığını devam ettirmesinin sebeplerinden birisinin de vakıfların iyi yönetilmesi olduğunu söylemek mümkündür.

Tablo 22: Vakıfların Gelir ve Giderlerinin Seyri (1184-1214/1770-1800)

\begin{tabular}{lcccc}
\hline Vakfın Adı & Murabaha & Kira & Vezâif & Mesârif \\
\hline Hâc Bedel Vakfı & - & Sabit & Sabit & Dalgalı \\
\hline Hâc Süleyman Vakfı & Artıyor & Artıyor & Sabit & Dalgalı \\
\hline Fatıma Hatun Vakfı & Sabit & - & Sabit & Sabit \\
\hline $\begin{array}{l}\text { Kâtip Hüseyin Efendi } \\
\text { Vakfı }\end{array}$ & Artıyor & Sabit & Sabit & Dalgalı \\
\hline Hâc İsmail Vakfı & Azalıyor & Sabit & Sabit & Dalgalı \\
\hline
\end{tabular}


Muhasebe kayıtları incelendiğinde vakıfların genel olarak masrafları sabit kalmakta, yıldan yıla önemli bir değişiklik göstermemektedir. Ancak bazı yıllarda zuhur eden tamir masrafları mesârifte dalgalanmaya sebep olmuştur. Vezâife gelince beş vakıf, 31 görev için 31 kişiye maaş ödemiş olup iki kişi hariç diğer bütün görevlilere ödenen maaş miktarı 30 y1l boyunca sabit kalmıştır. Dolayısıyla 30 yıllık bir periyotta tamirat masrafları sayılmazsa mesârif ve vezâifin önemli ölçüde sabit kaldığını söylemek mümkündür. Belli bir enflasyonun olduğu dönemde (Pamuk, 2012: 15-16) en azından kısa vadede bunun vakfın gelir ve giderlerine yansımaması dikkat çekmektedir.

Vakıfların kira gelirlerindeki seyre bakıldığında, kira geliri olan 4 vakıftan 3'ünün aldıkları kira miktarlarının 30 yıl boyunca sabit kaldığı, sadece Hâc Süleyman Vakfı'nın aldığı kira miktarında bir artı̧̧ olduğu görülmektedir. Murabaha gelirlerinin seyrine bakıldığında ise 4 vakfın murabaha geliri olup bunlardan birinin gelirinin sabit kaldığ 1 , birinin azaldığı diğer ikisinin ise arttı̆̆ görülmektedir.

Vakıfların böyle bir dönemde bile belli bir gelişim göstermeleri Osmanlı Devleti’nde vakıf kurumunun temellerinin ne kadar sağlam olduğunun ve halkın bu kurumlara her daim rağbet gösterdiğinin kanıtı mahiyetindedir. Vakıfların bu gelişimlerinde borç verirken genelde \%15 gibi yüksek bir oranla borç vermeleri, borç verilecek kişilerden sağlam bir teminat almaları en nihayetinde vakıfların iyi bir şekilde yönetilmelerinin önemli bir etkisinin olduğunu söylemek mümkündür.

Sonuç olarak vezâif ve mesârif giderlerinin ve kira gelirlerinin önemli ölçüde sabit kalmas1na mukabil vakıfların nakit sermayeleri ve murabaha gelirleri artmıştır. $\mathrm{Bu}$ artıştaki en önemli faktörün ise vakıfların artan gelirlerini nakit sermayelerine eklemeleri olduğu söylenebilir.

Tablo 23: Vakıflarda Görevlilere Ödenen Ortalama Maaş Miktarl (Akçe) (1184-1214/17701800)

\begin{tabular}{lccccccc}
\hline Vakfın Adı & $\begin{array}{c}\text { Hocaya } \\
\text { Ödenen Ort. } \\
\text { Miktar }\end{array}$ & $\begin{array}{c}\text { Halifeye } \\
\text { Ödenen Ort. } \\
\text { Miktar }\end{array}$ & $\begin{array}{c}\text { Şeyhe Ödenen } \\
\text { Ort. Miktar }\end{array}$ & $\begin{array}{c}\text { Mütevelliye } \\
\text { Odenen Ort. } \\
\text { Miktar }\end{array}$ & $\begin{array}{c}\text { Diğer Gör. } \\
\text { Odenen Ort. } \\
\text { Miktar }\end{array}$ & $\begin{array}{c}\text { Vezâif Ort. } \\
\text { Toplam }\end{array}$ & $\begin{array}{c}\text { Vakifların Ort. } \\
\text { Toplam Gideri }\end{array}$ \\
\hline Hâc Bedel & 2.520 & 1.440 & 1.800 & 1.080 & 1.440 & 8.280 & 11.069 \\
\hline Hâc Süleyman & 3.651 & 1.080 & - & 870 & 2.760 & 5.115 & 11.969 \\
\hline Fatıma Hatun & 1.440 & - & - & 360 & 360 & 2.160 & 2.370 \\
\hline Kâtip Hüseyin & 1.800 & 1.080 & - & 2.160 & 9.720 & 14.760 & 16.185 \\
\hline Hâc İsmail & 4.320 & 1.530 & - & 1.440 & 2.880 & 10.170 & 12.241 \\
\hline Toplam & $\mathbf{1 3 . 7 3 1}$ & $\mathbf{5 . 1 3 0}$ & $\mathbf{1 . 8 0 0}$ & $\mathbf{5 . 9 1 0}$ & $\mathbf{1 7 . 1 6 0}$ & $\mathbf{4 0 . 4 8 5}$ & $\mathbf{5 3 . 9 2 4}$ \\
\hline
\end{tabular}

Tabloda her bir vakfin bünyesindeki görevlilere ödedikleri maaş miktarlarının ortalamaları, vazifelilere ödenen toplam maaş miktarının ortalama miktarı ve vakıfların ortalama toplam giderleri yer almaktadır. Çalışmanın konusu mektep vakfı olduğu için vakıflarda çalışan eğitim görevlilerine ayrı olarak tabloda yer verilmiştir. Bunun yanı sıra vakfın sorumlusu olan mütevellilerin aldıkları maaşların toplam maaş miktarları içerisindeki payını görmek için tabloda 
mütevellilere de özel başlık açılmıştır. Eğitim görevlisi ve mütevellilik dışında görev yapan kimseler ise diğer başlı̆̆ altında gösterilmiştir.

Bünyesinde 3 görevliyle en fazla eğitim hizmetlisi bulunan vakıf, Hâc Bedel Vakfı olmasına karşın eğitim görevlilerine en fazla miktarda maaş ödeyen vakıf, Hâc İsmail Vakfı'dır. Fatıma Hatun Vakfı hariç diğer vakıfların hepsinde birden fazla eğitim görevlisi bulunmaktadır. 5 vakfın eğitim görevlilerine ödediği ortalama maaş miktarı toplamı 20.661 akçedir. Bu miktar vakıfların toplam ortalama gideri olan 53.924 akçenin \%38,3'üne, vazife ücretleri toplamı olan 40.485 akçenin ise \%51'ine denk gelmektedir. Mütevellilere ödenen ortalama maaş miktarlarının vazife ücretleri toplamı içerisindeki payı \%14,5, diğer görevlilerin payı ise $\% 42,3$ 'tür.

Vakıfların eğitim görevlisi olarak hizmet veren kişilerden en fazla ücreti hocaya ödedikleri görülmektedir. Mekteplerde çalışan en kıdemli görevliler hocalardır. Halifeler hocanın yardımcısı olduğu için doğal olarak daha düşük miktarda maaş almışlardır.

Çalışmada yer alan 5 mektep vakfından 4'ünün nakit sermayesinin olduğu ve çalışmanın zaman aralığı olan dönemde bu 4 vakıftan 2'sinin nakit sermayesinin önemli miktarlarda artış gösterdiği görülmektedir. Bir vakfın nakit sermayesi ise 30 yıl boyunca sabit kalmıştır. Bu durumun sebebi vâkıfın fazla kalan geliri vakfın imamına tahsis etmesidir. Bir vakfın ise nakit sermayesi borç verilen kişiden borcun tahsil edilememesi sebebiyle azalmıştır. Ancak bu vakfın da zaman içerisinde nakit sermayesinde meydana gelen erimeyi hızlı bir şekilde telafi ettiği ve çalışmanın son yılında nakit sermayesinin, düşüşe geçmeden önceki miktarına yaklaştığı görülmektedir. Buradan hareketle vakıfların mal varlıkları itibariyle genellikle büyüme trendi içerisinde olduklarını söylemek mümkündür.

\section{Sonuç}

Vakıflar, sahip oldukları nakit paraları -devlet tarafından belirlenmiş üst sınırı aşmamak kaydıyla- muamele-i şer'iyye, istiğlâl veya her iki yöntemle birlikte işletmekten gelir elde etmektedirler. Vakıfların bu şekilde elde ettikleri gelirlere murabaha denmektedir. Vakıfların bir diğer gelir kaynağı olan gayrimenkullerin kiralanması ise icare-i vahide, icareteyn ve mukâtaa usulleriyle olmaktadır. Ancak bu usullerden genellikle icareteynin tercih edildiği muhasebe kayıtlarından anlaşılmaktadır. Osmanlı ilmiyesinin geliştirdiği bu usulün, vakıfların lehine bir takım sonuçlar doğurduğu için tercih edildiği düşünülebilir.

Vakıfların hizmetlerini yerine getirmek için yaptıkları masraflar ve bünyelerinde çalışan görevlilere ödedikleri ücretler olmak üzere iki farklı gider kalemi bulunmaktadır. Vakıflar gelirlerini çok çeşitli alanlara kanalize etmişler ve bünyelerinde pek çok görevliyi istihdam etmişlerdir. Vakıflarda çalışan görevli sayısı genelde vakfın büyüklüğüyle doğru orantılı olmaktadır. Bunun yanında her hangi bir görevlinin vakıfta birden fazla görevi icra etmesi veyahut başka vakıflarda da çalışması mümkündür. Muhasebe kayıtlarından elde edilen bilgilere göre genellikle vakıfların vazifelilere ödedikleri toplam maaş miktarı masraf kalemlerinin toplam miktarından fazla olmaktadır. Bu da vakıfların kişiler için önemli bir geçim kaynağı olduğunu göstermektedir.

Vakıflarda görev yapan görevlilere ödenen maaşlar, vakıfların sahip oldukları mülklerden elde ettikleri kira miktarları ve kadılığa ödenen resmi harçlar Osmanlı-Rus savaşları esnasında 
ve sonraki dönemlerde yani 30 yıl boyunca istisnalar hariç sabit kalmıştır. Rus savaşlarından sonraki dönemde tağşişlerin artmasıyla birlikte akçenin alım gücü düşmüştür. Buna rağmen vakıf görevlilerinin maaşlarına, vakıf mülklerin kiralarına ve kadılığın tahsil ettiği harçlara zam yapılmamış olması dikkat çekmektedir.

Vakıflar elde ettikleri gelirleri vakfiyelerde yer alan cihetlere sarf etmişlerdir. Yani kuruluş amaçları doğrultusunda bu gelirleri harcamışlardır. Muhasebe kaydını incelediğimiz vakıfların genellikle gelirleri giderlerinden fazla olmuştur. Vakıfların gelir fazlalıklarının vakfın nakit sermayesine eklendiği veya mütevelli elinde ihtiyat akçesi olarak muhafaza edildiği ya da vâkıfın tahsis ettiği cihete verildiği tespit edilmiştir. Vakıfların hepsinin genel olarak gelir fazlasının olması mütevellilerin görevlerini yerine getirdiklerinin göstergesidir.

Sonuç olarak Osmanlı eğitim sisteminde vakıfların önemine vurgu yapmak gerekir. Tespit ettiğimiz mekteplerin, binalarına ait giderlerinin yanı sıra görevlilerin maaşları da dahil olmak üzere tüm ihtiyaçlarının ilgili vakıflar tarafından karşılandığı görülmektedir. 


\section{Kaynaklar}

\section{A. İstanbul Müftülüğü Şer’iyye Sicilleri Arşivi:}

Rumeli Mahkemesi 2 Numaralı Defter.

Üsküdar Mahkemesi 92, 203, 239, 435 Numaralı Defterler.

Üsküdar Mahkemesi 488 Numaralı Defter (1184-1188).

Üsküdar Mahkemesi 513 Numaralı Defter (1185-1198).

Üsküdar Mahkemesi 525 Numaralı Defter (1194-1203).

Üsküdar Mahkemesi 573 Numaralı Defter (1200-1225).

\section{B. Diğer Eserler:}

Akgündüz, Ahmet (2000). “İcare-i Vahide”. TDV İslam Ansiklopedisi, C. 21: s. 388-399.

Aydın, Bilgin vd. (2016). İstanbul Şer'iyye Sicilleri Vakfiyeler Kataloğu. İstanbul: İSAM Yayınları.

Baltac1, Cahit (2004). "Mektep”. TDV İslâm Ansiklopedisi C. 29: s. 6-7.

Bardak, Musa (2014). "XVIII. Yüzyıl Eğitim Öğretim Vakıflarına Bir Örnek: Sıbyan Mektebi ve Kütüphanesiyle Hacı Selim Ağa ve Vakfı”. International Journal of Social Science Research. 3(5): s. 1-32.

Berki, Ali Himmet (1940). Vakıflar. İstanbul: Cihan Kitaphanesi.

Berki, Ali Himmet ed. (1982). Mecelle-i Ahkâm-ı Adliyye. İstanbul: Hikmet Yayınları.

Birol, Nurettin (2004). “XIX. Yüzyıl Sonlarında Sivas Vilayeti’nde Müslüman Egitim-Ögretim Kurumları ve Faaliyetleri”. Atatürk Üniversitesi Türkiyat Araştırmaları Enstitüsü Dergisi (24): s. 209-32.

Durmuş, Muhammed Emin (2016). "Muhasebe Kayıtları Işı̆̆ında 18. Yüzyıl Son Çeyreğinde Üsküdar Para Vakıfları (1184-88/1770-74)”. Sakarya Üniversitesi SBE, (Yayınlanmamış Yüksek Lisans Tezi).

Durmuş, Muhammed Emin, Bektaş, İsmail (2017). “Osmanlı' da Muhasebe Usulü ve Vakıf Muhasebe Kayıtları Okuma Kılavuzu”. PESA Uluslararası Sosyal Araştırmalar Dergisi, 3(2): s. 196-209.

Gelişli, Yücel (2002). "Osmanlı Devleti İlköğretim Kurumlarından Sıbyan Mektepleri (Kuruluşu, Gelişimi, Dönüşümü)”. Türkler/Yeni Türkiye 15: s. 35-43.

Hızlı, Mefail (1998). “Osmanlı Dönemi Bursa’sında Eğitim-Öğretim Vakıflarına Genel Bir Bakış”. Uludağ Üniversitesi İlahiyat Fakültesi Dergisi 7(7): s. 183-191.

Hızlı, Mefail (2008). “Osmanlılarda İlköğretimin Tarihi”. Türkiye Araştırmaları Literatür Dergisi 6(12): s. 85-106.

Kaya, Süleyman (2007). "XVIII. Yüzyıl Osmanlı Toplumunda Nazari Ve Tatbiki Olarak Karz İşlemleri”. Marmara Üniversitesi SBE, (Yayınlanmamış Doktora Tezi). 
Kaya, Süleyman (2014). Osmanlı Hukukunda İcareteyn. İstanbul: Klasik Yayınları.

Özcan, Tahsin (2003). Osmanlı Para Vakıfları: Kanuni Dönemi Üsküdar Örneği. Ankara: Türk Tarih Kurumu.

Öztürk, Nazif (1995a). Elmalılı Hamdi Yazır Gözüyle Vakıflar. Ankara: TDV Yayınları.

Öztürk, Nazif (1995b). Türk Yenileşme Tarihi Çerçevesinde Vakıf Müessesesi. Ankara: TDV Yayınları.

Pakalın, Mehmet Zeki (1993a). Osmanlı Tarih Deyimleri ve Terimleri Sözlügü. İstanbul: MEB.

Pamuk, Şevket (2000). İstanbul ve Diğer Kentlerde 500 Ylllı Fiyatlar ve Ücretler 14691998. Ankara: Devlet İstatistik Enstitüsü.

Pamuk, Şevket (2012). Osmanlı Imparatorluğu’nda Paranın Tarihi. Ankara: TTK.

Sıdk1, Hasan (1308). Risale Bey've Şira. İstanbul: Ebuzziya Matbaası.

Tabakoğlu, Ahmet (1994). Türk İktisat Tarihi. 2. Bask1. İstanbul: Dergah Yayınları.

Ünal, Mehmet Ali (2011). Osmanlı Tarih Sözlüğ̈̈. İstanbul: Paradigma.

Yediyıldız, Bahaeddin (1983). "Vakıf Istılahları Lügatçesi”. Vakıflar Dergisi (17): s. 55-61.

Yediyıldız, Bahaeddin (1982). "Vakıf Müessesesinin XVIII. Asır Türk Toplumundaki Rolü”. Vakıflar Dergisi, 14: s. 1-27.

Yılmaz, Fehmi (2010). Osmanlı Tarih Sözlüğü. İstanbul: Gökkubbe Yayınları.

Yüksel, Hasan (1990). "Osmanlı Sosyal ve Ekonomik Hayatında Vakıfların Rolü Üzerine Bir Araştırma (1585-1683)”. Ankara Üniversitesi SBE, (Yayınlanmamış Doktora Tezi). 